\title{
Purex Processing of Dissolved Sand, Slag, and Crucible Containing High Levels of Boric Acid and Calcium Fluoride
}

by

E. A. Kyser

Westinghouse Savannah River Company

Savannah River Site

Aiken, South Carolina 29808

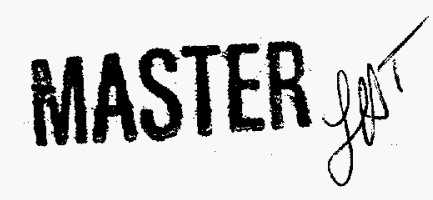

DETRIEUTON OF THSS DOCUMENT IS UNLMITED

DOE Contract No. DE-AC09-96SR18500

This paper was prepared in connection with work done under the above contract number with the U.S.

Department of Energy. By acceptance of this paper, the publisher and/or recipient acknowledges the U.S. Government's right to retain a nonexclusive, royalty-free license in and to any copyright covering this paper, along with the right to reproduce and to authorize others to reproduce all or part of the copyrighted paper. 


\section{DISCLAIMER}

This report was prepared as an account of work sponsored by an agency of the United States Government. Neither the United States Government nor any agency thereof, nor any of their employees, makes any warranty, express or implied, or assumes any legal liability or responsibility for the accuracy, completeness, or usefulness of any information, apparatus, product, or process disclosed, or represents that its use would not infringe privately owned rights. Reference herein to any specific commercial product, process, or service by trade name, trademark, manufacturer, or otherwise does not necessarily constitute or imply its endorsement, recommendation, or favoring by the United States Government or any agency thereof. The views and opinions of authors expressed herein do not necessarily state or reflect those of the United States Government or any agency thereof.

This report has been reproduced directly from the best available copy.

Available to DOE and DOE contractors from the Office of Scientific and Technical Information, P. O. Box 62, Oak Ridge, TN 37831; prices available from (423) 576-8401.

Available to the public from the National Technical Information Service, U. S. Department of Commerce, 5285. Port Royal Road, Springfield, VA 22161. 


\section{DISCLAIMER}

Portions of this document may be illegible in electronic image products. Images are produced from the best available original document. 


\section{Purex Processing \\ of}

Dissolved Sand, Slag and Crucible Containing High Levels

of

Boric Acid and Calcium Fluoride

Edward A. Kyser

May 1998

Westinghouse Savannah River Company

Savannah River Site

Aiken, SC 29808

Prepared for the U. S. Department of Energy under contract DE-AC09-96SR18500. 


\section{Purex Processing of Dissolved Sand, Slag and Crucible Containing High Levels of Boric Acid and Calcium Fluoride}

Edward A. Kyser

Issued May 1998

Technical Reviewers

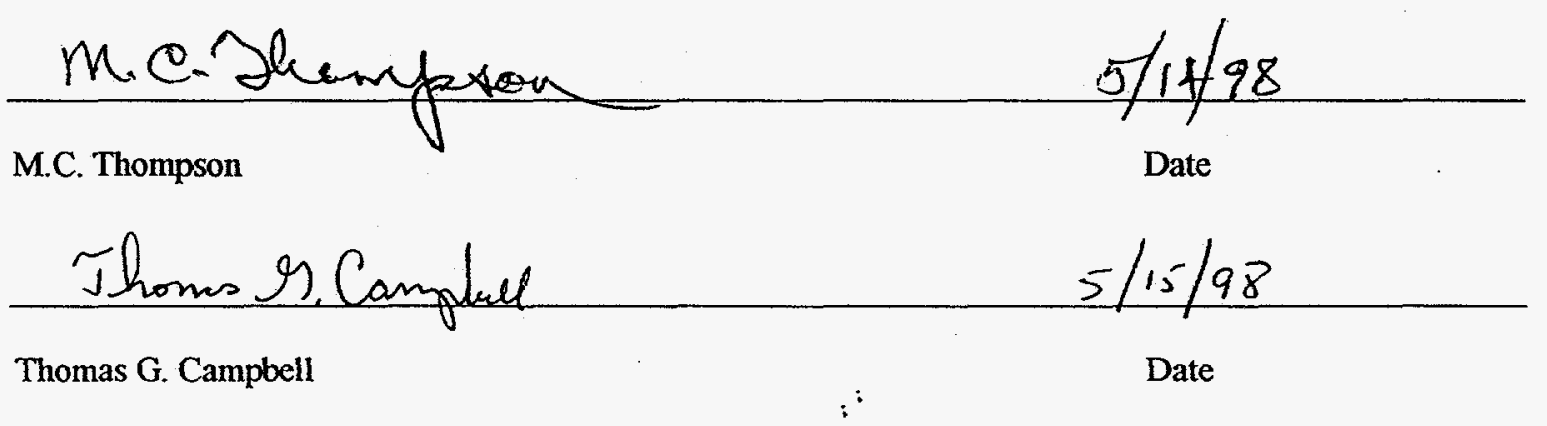


Table of Contents iii

List of Figures .

List of Tables iii

Acronyms and Definitions $\quad$ iv

Summary 5

Background 5

Historical Purex Processing in F-Canyon 5

Differences in the historical flowsheet for the current feedstock 6

$\begin{array}{ll}\text { Relevant Other Process Experience } & 6\end{array}$

Experimental $\quad 6$

Stripping Problems in Past Pickup Tests $\quad 6$

Standard Plutonium Pickup Test $\quad 6$

Simplified Plutonium/Impurity Pickup Test

Extraction only Pickup Test for Distribution Coefficient Determination $\quad 7$

$\begin{array}{ll}\text { Minibank Operation } & 7\end{array}$

Results and Discussion $\quad 7$

$\begin{array}{ll}\text { Extraction of Impurities into TBP } & 7\end{array}$

$\begin{array}{ll}\mathrm{Pu} \text { Extraction into TBP } & \mathbf{8}\end{array}$

Fluoride,Nitrate and Aluminum Effects on Plutonium Complexation and Extraction into TBP. 8

\begin{tabular}{ll} 
Computer Simulation & 12 \\
\hline &
\end{tabular}

Minibank Experimental Conditions and Results 13

$\begin{array}{ll}\text { Uncertainies } & 14\end{array}$

$\begin{array}{ll}\text { References } & 18\end{array}$

$\begin{array}{ll}\text { Appendix } & 19\end{array}$

\section{List of Figures:}

Figure 1. Pu $\mathrm{D}_{\mathrm{o} / \mathrm{a}}$ : Effects of Sulfate Compared to Effects of $\mathrm{F}$ and $\mathrm{Al}$. 9

Figure 2. Observed Pu $D_{o / a}$ Showing Effect of Al:F Ratio as a Function of Total Nitrate. 11

Figure 3. Observed $\mathrm{Pu} \mathrm{D}_{\mathrm{o} / \mathrm{a}}$ Showing Effect of Total Nitrate as a Function of Al:F Ratio. $\quad 11$

Figure 4. Calculated Effect of Acid Scrubbing with $2 \mathrm{AF}$ Containing $6 \mathrm{M} \mathrm{HNO}_{3}$.

Figure 5. Solvent Extraction Flowsheet for Minibank Operation. 14

Figure 6. 2A Bank Concentration Profiles from Minibank Experiments. 16

Figure 7. 2B Bank Concentration Profiles from Minibank Experiments. 16

Figure 8. Observed 2A Bank Pu $D_{o / a}$ from Minibank Experiments. . 17

Figure 9. Observed 2B Bank Pu $D_{\alpha / a}$ from Minibank Experiments. 17

List of Tables:

Table I. Distribution Coefficients for $\mathrm{HNO}_{3}, \mathrm{HF}$ and $\mathrm{B}(\mathrm{OH})_{3}$ with TBP.

Table II. Results from Pu108 Compared with Literature Values.

Table III. Pu108/9 Extraction Solution Preparation. 9

Table IV. Pu109 Impurity Extraction Results. $\quad$ - 9

Table V. Pu Extraction Test Results with Varying F, $\mathrm{NO}_{3}{ }^{-}$and Al. 10

Table VI. Pu-F and $\mathrm{Pu}-\mathrm{NO}_{3}{ }^{-}$Complexation Competition. 12

Table VII. Complexation Equations and Equilibrium Constants. 12

Table VIII. Feed Concentrations for the Minibank Runs. 13

Table IX. Flowrates, Pu Material Balance and Losses for Minibank Runs. 14

Table Al. Experimental Conditions and Results from Batch Extraction Tests. 19

Table A2. Measured Flowrates from Minibank Runs. $\quad 20$

Table A3. Detailed Sample Results from Minibank Run 1. 21

Table A4. Detailed Sample Results from Minibank Run 2. 22 
Acronyms and Definitions:

ANN, Al - Aluminum nitrate nonahydrate, source of aluminum used to complex fluoride

Bomb Reduction - Process by which FB-Line reduces $\mathrm{PuF}_{4} \mathrm{PuO}_{2}$ with metalic calcium to Pu metal

$\mathrm{Ca}, \mathrm{CaO}, \mathrm{CaF}_{2}-$ Calcium metal or compounds potentially in $\mathrm{SSC}$ residue.

$D_{o / a}$ - Distribution Coefficient, ratio of concentration in organic phase divided by concentration in aqueous phase

DBP - DiButyl Phosphate, Degradation production from TriButyl Phosphate resulting from the loss of a butyl group and replacement by an acid group. Forms a sodium salt in sodium carbonate solution and is stripped from the solvent.

F by ISE - SRTC analytical method for determination of total fluoride concentration utilizing an ion selective electrode with the sample pipeted into an acetic acid-sodium acetate buffer solution. The method appears to be unable fully compensate for the effects of the large amounts of boric acid and/or aluminum in high acid solutions used in this and related studies and tends to give results with a low bias.

FS, HAN - Ferrous Sulfamate and Hydroylamine Nitrate are the two primary reducing agents used to adjust Pu valence states in the Purex process.

Free acid - SRTC analytical method with uses $\mathrm{KF}$ to complex metal ions such as $\mathrm{Pu}$ to give the acid concentration without the effects of the metal ions.

Gamma Scan - Gamma counting method used in SRTC to determine the amount of Am241 in the samples after total alpha counting was performed by Radscreen. This allowed for the correction of the Radscreen results to calculate $\mathrm{Pu}$ concentrations.

GTM - Generalized Truex Model, Argonnel National Laboratory developed software and models used to develop solvent extraction flowsheets. SASSE was a calculational component developed to aid design of such processes.

HLW - High Level Waste, liquid waste containing actinides that will be transferred to the tank farm

ICPES - Inductively Coupled Plasma Emission Spectroscopy, Instrument used to analyze for certain cations such as Al and B

ILC-1 - Intermediate Level Cell \#1 laboratory where two banks of miniature mixer settler equipment is installed in a glovebox for Pu process development work.

$\mathrm{MgO}-\mathrm{Magnesium}$ oxide sand is used to fill void between crucible and pressure vessel

Pickup Test - SRTC development laboratory test that involves the extraction of Pu into TBP solvent followed by the stripping of the Pu from the solvent by weak acid solution containing HAN or FS. Test may be used to test either the solvent quality for extraction, followed by stripping or alternately to test the suitability of a given feed solution for extraction or followed by stripping.

$\mathrm{Pu}, \mathrm{PuO}_{2}, \mathrm{PuF}_{4}, \mathrm{PuF}_{3}-\mathrm{Pu}$ metal or compounds potentially in $\mathrm{SSC}$ residue

Radscreen - Liquid scintillation method used in SRTC for screening radioactive materials. In this work, the alpha counts were corrected from a general counting efficiency of $90 \%$ to a measured Pu efficiency of $97 \%$ to accurately determine total Pu and Am activity.

SASSE - Excel spreadsheet based macros developed by Argonne National Laboratory for the solution of material balances of countercurrent solvent extraction processes.

SEPHIS - Fortran computer code developed by Oak Ridge National Laboratory in 1975-9 for the solution of material balances of countercurrent solvent extraction processes. This code includes algorithms for the prediction of distribution coefficients for Pu and U based on TBP concentration, extractable and inextractable nitrate concentrations and $\mathrm{Pu}$ and $\mathrm{U}$ metal ion concentrations.

$\mathrm{Si}$ - An impurity that is known to be present in the $\mathrm{MgO}$ crucibles. It contributes heavily to phase disengagement problems in solvent extraction and is normally removed by gelatin strike and centrifugation

Slag - Solid hard mass of CaF2 - CaO that remains after Pu button breakout.

SOLVEX - Fortran computer code developed by SRS in 1975 for the solution of material balances of countercurrent solvent extraction process.

SSC - Sand, Slag and Crucible, residue in FB-Line Bomb Reduction charge after button removal, consists of small Ca and $\mathrm{Pu}$ metal shot and $\mathrm{PuO} 2$ trapped in $\mathrm{CaF} 2, \mathrm{CaO}$ slag, as well as $\mathrm{MgO}$ sand and crucible pieces

Strip - The removal of an extracted component (i.e. Pu) via contact with weak acid, reducing agent or complexant

TBP - TriButyl Phosphate is the extractant used in the Purex solvent extraction process. SRS uses a mixture of straight chain hydrocarbons called normal paraffin hydrocarbon (NPH) with an average carbon chain length of 12 to 14 as a diluent for its TBP processes.

TRUEX - TRansUranium EXtraction, General description given to various processes proposed for the separation of many component waste streams containing actinides via countercurrent flow solvent extraction.

Total acid - SRTC analytical method for determination of all species which are neutralized to $\mathrm{pH} 7$. 


\section{Summary}

The plutonium solution obtained from the dissolution of SSC in F-Canyon will be high in fluoride. Flowsheet adjustments must be made to increase the plutonium extraction in the solvent extraction cycle to keep $\mathrm{Pu}$ losses from being excessive. Either complexing the fluoride or increasing the total nitrate in the feed (2AF) stream will increase the plutonium extraction into TBP. The recommendation is to do minimal dilution of the dissolver solution to keep the nitrate high and to add sufficient ANN to give acceptable plutonium extraction. This minimizes additional waste generation from aluminum salts. The recommended target is to process the $2 \mathrm{AF}$ at $6 \mathrm{M}$ total nitrate with at least 0.5 molar ratio of aluminum to fluoride. This flowsheet has been experimentally verified in miniature mixer settler equipment in ILC-1 with total plutonium losses of 0.17 percent.

\section{Background}

In earlier work, modifications to the flowsheet for the dissolution of SSC in a nitric acid/boric acid solution in canyon dissolvers were developed ${ }^{1,2}$. SSC principally consists of $\mathrm{CaF}_{2}$ and $\mathrm{MgO}$ with lesser amounts of $\mathrm{CaO}, \mathrm{Ca}$ metal, $\mathrm{Pu}$ metal, $\mathrm{PuF}_{4}$ and $\mathrm{PuO}_{2}$. Boric acid had been added to the dissolution flowsheet as a neutron poison to increase the mass of $\mathrm{PuO} 2$ solids that would be safe in the dissolver in analyzed criticality senarios. The development of the current flowsheet came after the recognition that the high levels of boric acid had a significant complexation effect on the free fluoride in the solution. This caused a reduction in the rate of $\mathrm{PuO}_{2}$ dissolution as well as a dramatic increase in the rate of $\mathrm{CaF}_{2}$ dissolution. The latter allowed the elimination of the ANN that had been necessary for the dissolution of slag (primarily composed of $\mathrm{CaF}_{2}$ ). Due to the high F:Pu ratio in the dissolver solution and the removal of ANN from the flowsheet, the potential for $\mathrm{PuF}_{\mathrm{x}}$ complexes to interfere with either the $\mathrm{Pu}$ extraction or the $\mathrm{F}$ decontamination was recognized. Investigation of these issues was the thrust of the work described in this report.

\section{Historical Purex Processing in F-Canyon}

Typical Purex feed consisted of target or fuel slugs with a uranium core and aluminum cladding. The cladding was removed in the dissolver with $\mathrm{a} \mathrm{NaOH} / \mathrm{NaNO}_{3}$ solution that was recycled for repeated decladdings or discarded. The irradiated uranium core (which contained $\mathrm{Pu}$ ) was then dissolved in $50 \% \mathrm{HNO}_{3}$. Typically the solution acidity was depleted during the dissolution operation to less than $2 \mathrm{M} \mathrm{HNO}_{3}$ (due to oxidation reactions with generation of $\mathrm{NO}_{x}$ and $\mathrm{H}_{2} \mathrm{O}$ ). The solution containing the dissolved $\mathrm{U}$ and $\mathrm{Pu}$ was then transferred through head end in batches. Gelatin strike was performed by adding gelatin, simmering the solution and then promptly centrifuging to remove solids. The gelatin removed silica by forming a gelatinsilica polymer, which was removed in the centrifuge along with any other solids. Silica was removed to prevent formation of solids that cause emulsions in solvent extraction equipment during later processing. The U-Pu solution was then adjusted to make it suitable for 1st Uranium Cycle processing.

1st Uranium Cycle feed was approximately $300 \mathrm{~g} \mathrm{U} / \mathrm{h}, 1 \mathrm{M} \mathrm{HNO}_{3}$, with small amounts of $\mathrm{Al}, \mathrm{Pu}$ (IV) and fission products. The $U$ and Pu were extracted into the $30 \%$ TBP solvent into the $1 \mathrm{~A}$ bank. Pu was reductively stripped from the solvent in the $1 \mathrm{~B}$ bank with $\mathrm{FS}$ or $\mathrm{FS} / \mathrm{HAN}$ in $\approx 0.1 \mathrm{M} \mathrm{HNO}_{3}$. The solvent retained the $\mathrm{U}$ until it was stripped in the $1 \mathrm{C}$ bank. The $\mathrm{Pu}$ in the $1 \mathrm{BP}$ stream was $\mathrm{Pu}$ (III) in $\mathrm{HNO}_{3}$, FS, Ferric Sulfate, HAN solution. Prior to being fed to the 2 nd Pu cycle, the Pu valence was adjusted from III to IV by oxidizing the $\mathrm{Fe}(\mathrm{m})$ with $\mathrm{NaNO}_{2}$. This was performed by the addition of sufficient nitrite to react with the remaining sulfamate. Excess nitrite then oxidized the Fe(II) and $\mathrm{Pu}(\mathrm{III})$. The $\mathrm{Pu}(\mathrm{IV})$ solution was adjusted to the desired $2 \mathrm{AF}$ feed condition of $4 \mathrm{M} \mathrm{HNO}_{3}$ and approximately $0.5 \mathrm{~g} \mathrm{Pu} / \mathrm{l}$.

The $2 \mathrm{AF}$ stream typically contained as much as $0.17 \mathrm{M} \mathrm{SO}_{4}$ as well as $\mathrm{NaNO} 3$ and $\mathrm{Fe}(\mathrm{III})$. This level of sulfate in the $4 \mathrm{M} \mathrm{HNO}_{3}$ reduced the $\mathrm{Pu} \mathrm{D}_{\mathrm{o} / \mathrm{a}}$ from the range of 15 to 20 down to the range of 7 to 8 . In the extraction stages of the $2 \mathrm{~A}$ bank, the Pu and trace amounts of $\mathrm{U}$ were extracted into the $30 \%$ TBP solvent, while the $\mathrm{Na}, \mathrm{SO}_{4}, \mathrm{Fe}$ and fission products were removed in the $2 \mathrm{AW}$ stream. The $2 \mathrm{~A}$ bank used a scrub acid of 0.66 $\mathrm{M} \mathrm{HNO} 3$ at $30 \%$ of the flow rate of the $2 \mathrm{AF}$. This reduced the level of extracted $\mathrm{HNO}_{3}$ in the solvent to approximately $0.12 \mathrm{M}$ in the $2 \mathrm{AP}$ stream. Extracted $\mathrm{Pu}$ in the solvent is transferred to stage 12 of the $2 \mathrm{~B}$ bank via the $2 \mathrm{AP}$ stream. The $2 \mathrm{BX}$ stream consists of a low flowrate of $0.1 \mathrm{M} \mathrm{HAN}, 0.1 \mathrm{M} \mathrm{HNO}$ that reductively stripped the Pu from the solvent stream. The solvent, after it was stripped of $\mathrm{Pu}$, was then recycled via the solvent recovery system. The $U$ rejection flowsheet involved the addition of a $2 \mathrm{BS}$ stream, which was $30 \%$ TBP, to stage 16. This flowsheet provided some uranium rejection capability to the 2 nd Pu cycle process. With the 4 scrub stages in the $2 B$ bank, $U$ tended to remain with the solvent and was transferred to solvent recovery rather than being stripped into the 2BP-product stream. 
If excessive $\mathrm{HNO}_{3}$ remained in the $2 \mathrm{AP}$ stream, it could interfere with the reductive stripping of Pu by HAN in the 2B bank and cause excessive refluxing of $\mathrm{Pu}$ in the 2B bank increasing the $\mathrm{Pu}$ inventory in the equipment. It appears that by design, the $2 \mathrm{AS}$ flowrate and $\mathrm{HNO}_{3}$ concentration in the $2 \mathrm{AS}$ control the $\mathrm{HNO}_{3}$ content of the 2AP stream ${ }^{3}$. With the modifications introduced to the B bank with the Uranium Rejection flowsheet, the critical variables that prevent excessive Pu refluxing were the $2 \mathrm{BX}$ flowrate and HAN concentration in the $2 \mathrm{BX}$.

Small amounts of residual Pu activity, the rejected $U$ and degradation products such as DBP were removed in the carbonate wash tank of the solvent recovery system using 2.5 weight percent $\mathrm{Na}_{2} \mathrm{CO}_{3}$. The solvent was washed in $0.1 \mathrm{M} \mathrm{HNO}_{3}$ prior to being returned to the solvent storage tank. The entire 2nd Pu cycle process normally operated in the 35 to $50^{\circ} \mathrm{C}$ range.

The 2BP product consisted of 2.5 to $3.5 \mathrm{~g} / \mathrm{Pu}$ (III) in approximately 0.3 to $0.4 \mathrm{M} \mathrm{HNO}_{3}, 0.06 \mathrm{M}$ HAN. This solution was later transferred to FB-Line for concentration by cation exchange, precipitation as $\mathrm{PuF}_{3}$ and eventual reduction to $\mathrm{Pu}$ metal via Ca metal in Bomb Reduction. After button breakout, some of the $\mathrm{MgO}$ sand, much of the $\mathrm{MgO}$ crucible, excess $\mathrm{Ca}$ metal and the $\mathrm{CaF}_{2}-\mathrm{CaO}$ slag, became the $\mathrm{SSC}$ residue that is the subject of this report. Unreduced $\mathrm{PuO}_{2}-\mathrm{PuF}_{4}$ and small pieces of $\mathrm{Pu}$ metal provided the incentive to retain this material for recovery.

Differences in the historical flowsheet for the current feedstock: SSC is significantly different in composition from the traditional uranium metal targets that were processed in F Canyon. Since there is no uranium or fission products in SSC, there was no incentive to process this material in 1st uranium cycle. Dissolving metal targets consumed much of the acid in the dissolver in historical processing. By comparison, SSC should consume very little acid. This is a difference that affects chemistry of gelatin strike for silica removal. The high levels of fluoride (from $\mathrm{CaF}_{2}$ and $\mathrm{KF}$ ) both complex $\mathrm{Pu}$, thereby reducing its extractability into TBP, and further complicating gelatin strike with the chemical interactions between silica and fluoride. The high levels of boron do complex fluoride, but not as strongly as $\mathrm{Al}$ or $\mathrm{Pu}$. Current plans are to avoid the use of sulfamate. The additional complexation caused by sulfate in addition to the fluoride would further complicate the extraction of the $\mathrm{Pu}$.

Relevant Other Process Experience: There are some other separations processing experiences that have some relevance to the current chemistry. The traditional processing of $\mathrm{SSC}$ involved $\mathrm{HNO}_{3}$ dissolution in $\mathrm{FB}-\mathrm{Line}$ with large amounts of ANN to complex the $F$. Boric acid was not needed because processing was performed in geometrically favorable equipment. This process had problems with leftover solid residues left in the dissolver due to solubility limitations. This solution was processed through anion exchange to recover the Pu from the large amounts of $\mathrm{Al}, \mathrm{Ca}$ and $\mathrm{F}$ present. At $8 \mathrm{M} \mathrm{HNO}_{3}$ and with a minimum of 1.5 moles $\mathrm{Al}$ per $\mathrm{F}, \mathrm{Pu}$ was recovered on anion exchange as an anionic $\mathrm{Pu}$ nitrate complex. The combination of high $\mathrm{HNO}_{3}$ and aluminum complexation of fluoride allowed the Pu to be separated from the fluoride. Scrub alloy processing and Pu metal dissolution in F-Canyon have some similar aspects to the current SSC recovery process. However the relative amounts of $\mathrm{Pu}, \mathrm{F}, \mathrm{Al}$, and $\mathrm{B}$ in the dissolver solution were quite different from the SSC solutions.

\section{Experimental}

Stripping Problems in Past Pickup Tests: The inability to completely strip Pu from SRTC prepared solvent was a observation in earlier work. In pickup/stripping tests described in Ref 2, Pu was not stripped below $10^{5}$ $\mathrm{dpm} / \mathrm{ml}$. Those stripping difficulties were traced to a batch of $n$-paraffin diluent used in the preparation of the $30 \%$ TBP solvent. Some unidentified impurity was present which retained a small amount of $\mathrm{Pu}$ in the absence of 'TBP. All solvent tests described in the current work, used either solvent from the F-Area Outside Facilities 906 solvent storage tank or solvent prepared from another source of diluent that was proven to not exhibit this extraction behavior.

Standard Plutonium Pickup Test: A relatively standard plutonium pickup test was performed in past work ${ }^{2}$ with adjusted dissolver solutions to test the extractability/stripability of the plutonium. After feed adjustment, an equal volume of freshly prepared and triple washed solvent was used to extract the plutonium from the adjusted sample. Each step of the procedure included a one minute vortex mixing followed by a two minute centrifugation. After removal of the extracted aqueous phase, batch scrub and strip steps of $0.1 \mathrm{M} \mathrm{HNO} / 0.1 \mathrm{M}$ HAN were performed to demonstrate the stripping of the plutonium from the solvent. Each phase was sampled and analyzed for alpha content by liquid scintillation counting. Due to the Am241 in the feed material, both 
aqueous and organic solutions were analyzed for Am24lby gamma scan and the total alpha results were corrected for the Am241 ingrowth. The free acid-total acid was measured on both aqueous and organic samples to assure that proper feed adjustment had been performed and to determine the $\mathrm{D}_{\mathrm{o} / \mathrm{a}}$ for the acid species. All batch extraction tests were performed at $22-23^{\circ} \mathrm{C}$.

Simplified Plutonium/Impurity Pickup Test: The standard pickup test involved a large number of strips. The first four serve to scrub out the extracted acid to allow HAN to reduce the plutonium (IV) to plutonium (III) so that the plutonium easily strips out of the solvent. However, with the large number of strips, it is not possible to sample each phase at each stage due to the amount of sampling involved. A simplified test that used essentially equal volumes of strip acid to scrub the acid from the organic in one stage was developed. Three strip/scrub stages were used and both an aqueous and an organic sample were taken from the extraction and each strip stage. This procedure allowed a plutonium material balance to be performed and for Pu distribution coefficients to be calculated for each stage. All batch extraction tests were performed at $22-23^{\circ} \mathrm{C}$.

Due to the nitrate variation from the addition of nitrate salts such as aluminum, all tests used an adjustment based on calculated total nitrate rather than total or free acid. Extraction/Strip tests were performed in a $15 \mathrm{ml}$ glass centrifuge tube for plutonium. Five ml of adjusted feed were extracted. The same centrifuge was retained throughout both the extraction and strip steps. Each strip used 5 milliliters of $0.1 \mathrm{M} \mathrm{HNO} / 0.1 \mathrm{M} \mathrm{HAN}$ in contact with $4.5 \mathrm{ml}$ down to 2 to $3 \mathrm{ml}$ of the remaining organic phase in the centrifuge tube. A parallel test was performed with identical feed solutions to observe the behavior of the impurities of concern such as boron and fluoride. For impurity studies, the organic phase was contacted with 1 or $2 \mathrm{M} \mathrm{NaOH}$ solution to strip the extracted acidic species (principally $B$ or $F$ ) into an aqueous phase that was then analyzed by ICPES and F by ISE. Vortex mixing and centrifugation were standard steps in all variants of the pickup test. All batch extraction tests were performed at $22-23^{\circ} \mathrm{C}$.

Extraction Only Pickup test for Distribution Coefficient Determination: An extraction only test was also used. In this test, a solution was prepared by dissolving boric acid, ferric nitrate, calcium fluoride, concentrated $\mathrm{HNO}_{3}$, deionized water and/or $0.1 \mathrm{M} \mathrm{HNO}$ either by pipeting solution or by weighing on an analytical balance. After introducing this solution to the glovebox a well-characterized solution of plutonium (IV) nitrate in nitric acid was pipeted into the solution matrix to obtain the desired plutonium and nitrate concentrations to simulate the dissolver solution. Three $\mathrm{ml}$. of the dissolver solution was then pipeted into a previously prepared vial containing weighed amounts of $\mathrm{ANN}$ dissolved in $0.1 \mathrm{M} \mathrm{HNO}_{3}$ to obtain the desired $\mathrm{Pu}, \mathrm{NO}_{3}$, and $\mathrm{Al}: \mathrm{F}$ conditions. Two $\mathrm{ml}$. of each vial was then pipeted into two $\mathrm{ml}$ of 30 percent TBP solvent in a $15 \mathrm{ml}$ glass or plastic centrifuge tube. These solutions were then vortex mixed and centrifuged as was done in the standard pickup tests and each phase was sampled for analyses by the Radscreen, Gamma scan, and/or Total acid/Free acid methods. This allowed for calculation of distribution coefficients for $\mathrm{Pu}, \mathrm{Am}$, and/or Free acid between the phases. Gamma scan results for Am241 were used to correct the Radscreen alpha results and many times could be and were accurately estimated rather than measured.

Minibank Operation: Minibanks are miniature mixer settlers on the order of $1 / 10000^{\text {th }}$ scale of canyon-sized equipment. Although the design is quite different from F-Canyon mixer setters, this lab equipment has a long history of use for process development for counter-current-flow solvent extraction flowsheets for both $F$ and $H$ Canyons. The minibank equipment installed in the glovebox in ILC-1 was utilized to perform flowsheet demonstrations for this work. This equipment and its operation has been described in general terms in a number of past reports and will not be discussed in detail here. The equipment was operated without computer control. An HP8452A diode array spectrophotometer was utilized to perform online monitoring of the Pu concentrations in the 2BP and 2AW streams. Plant solvent from the 2nd Plutonium Cycle containing 30\% TBP was obtained for these runs. Anion exchange purified Pu nitrate solution was used for a Pu source material. HAN solution obtained from FB-Line was used as a reductant. Reagent grade chemicals were used for the other necessary chemicals. Temperature was at laboratory ambient, approximately $25-27^{\circ} \mathrm{C}$ for both experiments.

\section{Results and Discussion:}

Extraction of Impurities into TBP: A literature review suggested that fluoroboric acid $\left(\mathrm{HBF}_{4}\right)$ may extract into the solvent. Table 1 shows the distribution coefficients compiled by Shultz $\mathrm{z}^{4}$ that appear applicable to this system along with results from the current study. Note that the distribution coefficients for both $\mathrm{HF}$ and boric 
acid go up as the acid concentration goes down. This trend suggests that when fluoride and boron extract they will not easily strip back from the solvent. ANN added in the feed solution will suppress the initial extraction of these fluoride species due to competition for the fluoride, but should not affect the boric acid extraction.

Table I. Distribution Coefficients for $\mathrm{HNO}_{3}, \mathrm{HF}$ and $\mathrm{B}(\mathrm{OH})_{3}$ with TBP.

\begin{tabular}{|c|c|c|c|c|c|c|}
\hline HNO3, $\mathrm{M}$ & $\mathrm{HNO}^{1}$ & $\mathrm{HF}^{2}$ & $\mathrm{~B}(\mathrm{OH})_{3}{ }^{3}$ & $\mathrm{HF}^{4}$ & $\mathrm{~B}(\mathrm{OH})_{3}^{3}$ & $\mathrm{H}+\mathrm{free}^{3}$ \\
\hline 0.1 & 0.05 & & & & & \\
\hline 0.5 & 0.1 & 0.4 & & & & \\
\hline 1 & 0.15 & 0.3 & 0.15 & & & \\
\hline 2 & 0.2 & 0.2 & 0.08 & & & \\
\hline 3 & 0.2 & 0.15 & 0.04 & & & 0.16 \\
\hline 4 & 0.2 & 0.1 & 0.007 & $0.05-0.08$ & $0.03-0.05$ & $0.15-0.16$ \\
\hline 5 & 0.2 & 0.05 & & & & $0.14-0.26$ \\
\hline 6 & 0.17 & 0.03 & & & & $0.13-0.25$ \\
\hline 7 & & & & & & $0.13-0.16$ \\
\hline $0.5 \mathrm{M} \mathrm{HF}^{7}$ & & & 0.44 & & & \\
\hline
\end{tabular}

${ }^{1}$ Solvent was $30 \%$ TBP $19-23^{\circ} \mathrm{C}$ Data smoothed, Reference 4.

${ }^{2}$ Solvent was $30 \%$ TBP in DEB $19-23^{\circ} \mathrm{C}$, Data smoothed, Reference 4.

${ }^{3}$ Solvent was $100 \%$ TBP $19-23^{\circ} \mathrm{C}$, Reference 4.

${ }^{4}$ Solvent was $30 \%$ TBP in NPH, $\mathrm{Pu}, \mathrm{F}$ and $\mathrm{B}(\mathrm{OH})_{3}$ present, No $\mathrm{Al}$, Pu109.

'Solvent was $30 \%$ TBP in NPH, $\mathrm{Pu}, \mathrm{F}$ and $\mathrm{B}(\mathrm{OH})_{3}$ present, No Al, Pul09.

${ }^{6}$ Solvent was $30 \%$ TBP in NPH, $\mathrm{Pu}, \mathrm{Al}, \mathrm{F}$ and $\mathrm{B}(\mathrm{OH})_{3}$ present, Pu1 10-18.

${ }^{7}$ Solvent was $100 \% \mathrm{TBP}$, not clear if $\mathrm{HNO}_{3}$ was present, $19-23^{\circ} \mathrm{C}$, Reference 4 .

The earlier work ${ }^{2}$ where $\mathrm{B}$ and $\mathrm{F}$ extraction was studied without $\mathrm{Pu}$, showed that 2 to $5 \%$ of the boron and fluoride remained in the solvent (when ANN was not present) and was stripped in the first contact with weak acid. However the literature $\mathrm{D}_{\mathrm{o} / \mathrm{a}}$ values show a relationship that is inversely proportional to the acid concentration. Since the solvent was not analyzed for fluoride or boron, it is not certain that all the fluoride was removed from the solvent. For a single test run with an Al:F ratio of $1: 1$, the fluoride extraction was reduced to about 1 percent. With an Al:F ratio of 4:1, the extraction was further reduced to tenths of a percent. With $\left[\mathrm{HNO}_{3}\right]=9.9 \mathrm{M}$, both fluoride and boron extractions appeared to be suppressed due to mass action competition with $\mathrm{HNO}_{3}$.

Pu Extraction into TBP: Pickup Test Pu108 was the first Pu test run performed without any Al present. All earlier Pu extract tests used relatively high levels of $\mathrm{Al}$ to investigate the effects of those high levels of $\mathrm{Al}$ in the solvent extraction process. The high levels of $\mathrm{Al}$ enhanced the Pu extraction both by complexation of the $\mathrm{F}$ and by salting. Without $\mathrm{Al}$ in the feed, the Pu extraction was dramatically reduced. Test Pul08 corresponded to dissolver concentrations of 0 to $0.21 \mathrm{M}$ boron and 0.05 to $0.52 \mathrm{M}$ fluoride at $9.5 \mathrm{M} \mathrm{HNO}_{3}$. A summary of the results is shown in Table II with more complete results included in the appendix as Table Al. The dramatic

Table II. Results from Pu108 Compared with Literature Values.

\begin{tabular}{lllll}
\hline & B, M & F, M & NO3-, M & Pu D o/a \\
\hline Pu108A & 0.070 & 0.162 & 3.9 & 0.22 \\
Pu108B & 0.070 & 0.081 & 3.9 & 0.38 \\
Pu108C & 0.070 & 0.016 & 3.9 & 1.26 \\
Pu108D & 0 & 0.017 & 4.2 & 0.59 \\
Literatures $^{5}$ & 0 & 0 & 4 & $20+$ \\
0.17 M SO4 $^{3}$ & 0 & 0 & 4 & 7 to 8 \\
\hline
\end{tabular}

difference when fluoride is present with the literature values, either with or without sulfate is better shown in Figure 1. By comparing the $\mathrm{D}_{\alpha \mathrm{a}}$ for Pul08C and Pu108D it is noted that even at a B:F molar ratio of 4 , boron has only a modest effect on the Püextraction when compared with later results with Al. The

competition between Pu fluoride and Pu nitrate complexation appears to heavily favor fluoride in $4 \mathrm{M} \mathrm{HNO}_{3}$. Impurity extraction test Pu109 was performed with the same feed solution as Pu108 and was done to quantify the extent that Pu might assist the extraction of boron and fluoride into the solvent. There was concern that $\mathrm{PuF} 4$ or $\mathrm{PuF}_{\mathrm{x}}\left(\mathrm{NO}_{3}\right)_{4-\mathrm{x}}$ might significantly increase the carryover of $\mathrm{F}$ into the scrub stages. The makeup of Pu108/9 and the results are shown in Tables III and IV. These results are consistent with the values estimated in earlier work when Pu was not present ${ }^{2}$. Due to a low bias in the fluoride analytical results when boron or aluminum was present, the $D_{o / 3}$ for $F$ is likely biased high by about $30 \%$. Note that since this test did not involve any ANN, any addition of ANN should further reduce the amount of fluoride extracted.

Fluoride,Nitrate and Aluminum Effects on Plutonium Complexation and Extraction into TBP: Based on the low values for the $\mathrm{Pu} \mathrm{D}_{\mathrm{o} / \mathrm{a}}$ observed in Pu108, it is apparent that a chemical change to significantly increase the Pu extraction was needed. The options considered were diluting the $\mathrm{F}$, complexing the $\mathrm{F}$ with $\mathrm{Al}$ or increasing the total nitrate concentration. Dilution is undesirable as the $\mathrm{Pu}$ concentration from the dissolution 
Table III. Pu108/9 Extraction Solution Preparation. $\left(22-23^{\circ} \mathrm{C}\right)$

\begin{tabular}{cccccccccccccc}
\hline \multirow{2}{*}{ Description } & Pu & Acid & F & B & Al & Pu & NO3 & Fe & Ca & F & B & Ca & Fe \\
& g/1 & M & M & M & M & M & M & g/ & M & ppm & ppm & ppm & ppm \\
\hline Pu108/9A & 2.08 & 10.0 & 0.52 & 0.21 & 0.00 & 0.009 & 9.49 & 2.2 & 0.26 & 9867 & 2269 & & \\
Pu108/9B & 2.08 & 10.0 & 0.26 & 0.21 & 0.00 & 0.009 & 9.49 & 2.2 & 0.13 & 4933 & 2269 & & \\
Pu108/9C & 2.08 & 10.0 & 0.05 & 0.21 & 0.00 & 0.009 & 9.49 & 2.2 & 0.03 & 987 & 2269 & & \\
Pu108/9D & 2.08 & 9.4 & 0.05 & 0.00 & 0.00 & 0.009 & 9.49 & 2.2 & 0.03 & 987 & 0 & & \\
& & & & & & & & & & & & & \\
Pu108/9A Adj & 0.65 & 4.1 & 0.16 & 0.07 & 0.00 & 0.003 & 3.92 & 0.70 & 0.08 & 3074 & 707 & 3242 & 699 \\
Pu108/9B Adj & 0.65 & 4.1 & 0.08 & 0.07 & 0.00 & 0.003 & 3.92 & 0.70 & 0.04 & 1537 & 707 & 1621 & 699 \\
Pu108/9C Adj & 0.65 & 4.1 & 0.02 & 0.07 & 0.00 & 0.003 & 3.92 & 0.70 & 0.008 & 307 & 707 & 324 & 699 \\
Pul08/9D Adj & 0.69 & 4.1 & 0.02 & 0.00 & 0.00 & 0.003 & 4.18 & 0.75 & 0.009 & 328 & 0 & 346 & 746 \\
\hline
\end{tabular}

Table IV. Pu109 Impurity Extraction Results. $\left(22-23^{\circ} \mathrm{C}\right)$

\begin{tabular}{lcccccccc}
\hline & \multicolumn{1}{c}{ Analyzed } & \multicolumn{7}{c}{ D o/a } \\
& F & B & Ca & Fe & F & B & Ca & Fe \\
& ppm & ppm & ppm & ppm & & & & \\
\hline Pul08/9A Adj & 2086 & 780 & 3665 & 735 & 0.081 & 0.05 & 0.001 & 0.002 \\
Pu108/9B Adj & 1175 & 758 & 1878 & 771 & 0.071 & 0.03 & 0.001 & 0.002 \\
Pu108/9C Adj & 212 & 731 & 286 & 789 & 0.055 & 0.03 & 0.009 & 0.003 \\
Pu108/9D Adj & 201 & 20 & 251 & 718 & 0.066 & n/a & 0.009 & 0.002 \\
\hline
\end{tabular}

Figure 1. Pu $\mathrm{D}_{\mathrm{o} / \mathrm{a}}$ : Effects of Sulfate Compared to Effects of $\mathrm{F}$ and Al. $\left(22-25^{\circ} \mathrm{C}\right)$

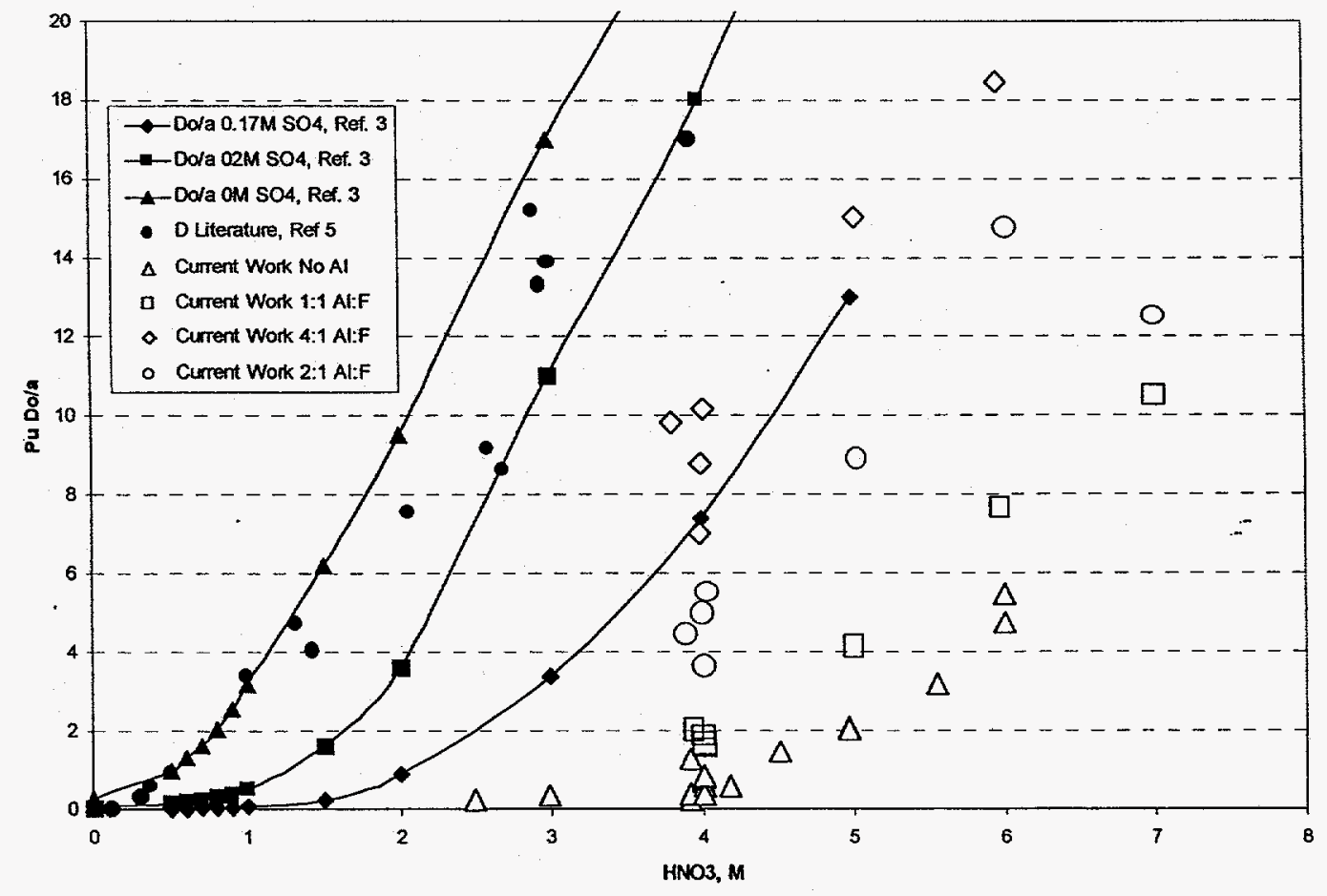


Table V. Pu Extraction Test Results with Varying $\mathrm{F}, \mathrm{NO}_{3}{ }^{-}$and Al.

\begin{tabular}{|c|c|c|c|c|c|c|c|c|c|}
\hline Sample & ID & $\begin{array}{c}\mathrm{F} \\
\mathrm{M} \\
\end{array}$ & $\begin{array}{c}\text { NO3- } \\
\mathrm{M} \\
\end{array}$ & Al: $F$ & $\mathrm{~F}: \mathrm{Pu}$ & & $B: F$ & $\begin{array}{c}\mathrm{Pu} \\
\mathrm{mg} / \mathrm{l}\end{array}$ & $\begin{array}{c}D \\
\text { O/A }\end{array}$ \\
\hline Pu110A & $A \mid F=0 \quad N O 3=4$ & 0.11 & 4.01 & 0.00 & 29 & 1067 & 0.8 & 923 & 0.80 \\
\hline Pul10B & $\mathrm{AlF}=0.25 \mathrm{NO} 3=4$ & 0.11 & 4.04 & 0.25 & 29 & 1089 & 0.8 & 907 & 1.02 \\
\hline Pu110C & $\mathrm{AIF}=0.5 \mathrm{NO}=4$ & 0.10 & 4.01 & 0.49 & 29 & & 0.8 & 879 & 1.19 \\
\hline Pu110D & $\mathrm{AlF}=1 \mathrm{NO}=4$ & 0.10 & 4.01 & 1.01 & 29 & & 0.8 & 838 & 1.69 \\
\hline & $A \mathrm{AF}=\mathbf{2} \mathrm{NC}$ & 0.09 & 4.01 & 2.03 & 29 & & 0.8 & 767 & 3.66 \\
\hline & AlF $=3 \mathrm{~N}$ & 0.09 & 3.99 & 3.00 & 29 & & 0.8 & 707 & 5.54 \\
\hline & AIF $=4 \mathrm{~N}$ & 0.08 & 3.99 & 4.02 & 29 & & 0.8 & 656 & 7.00 \\
\hline & $\mathrm{AlF}=\mathbf{0} \mathrm{NC}$ & 0.15 & 4.01 & 0.00 & 39 & & 0.5 & 971 & 0.58 \\
\hline & $\mathrm{AlF}=0.25$ & 0.14 & 4.02 & 0.25 & 39 & & 0.5 & 954 & 0.75 \\
\hline & $\mathrm{AIF}=0.5$ & 0.14 & 4.02 & 0.51 & 39 & & 0.5 & 924 & 0.92 \\
\hline & $\mathrm{AlF}=1$ & 0.13 & 4.01 & 0.99 & 39 & & 0.5 & 881 & 1.54 \\
\hline & $\mathrm{AlF}=2 \mathrm{~N}$ & 0.12 & 4.03 & 2.03 & 3 & & 0.5 & 807 & 5.52 \\
\hline $11 \mathrm{~F}$ & $A \mid F=3 N$ & 0.11 & 4.03 & 3.02 & 3 & & 1.5 & 744 & 7.43 \\
\hline & $\mathrm{AlF}=4 \mathrm{~N}$ & 0.10 & 4.02 & 3.99 & 3 & & 1.5 & 690 & 10.16 \\
\hline & $\mathbf{A l F}=0 \mathrm{~N}$ & 0.11 & 4.01 & 0.00 & & & 1.0 & 965 & 0.40 \\
\hline $2 \mathrm{~B}$ & $\mathrm{AlF}=0.25 \mathrm{I}$ & 0.11 & 4.02 & 0.25 & & & .0 & 947 & 0.58 \\
\hline & AlF $=0.5 \mathrm{~N}$ & 0.10 & 3.98 & 0.51 & & & 0.0 & 918 & 0.87 \\
\hline $2 \mathrm{D}$ & $\mathbf{A l F}=1 \mathrm{~N}$ & 0.10 & 3.95 & 1.01 & & & 0.0 & 875 & 2.03 \\
\hline & AlF $=2 \mathrm{~N}$ & 0.09 & 3.89 & 2.04 & & & .0 & 801 & 4.45 \\
\hline & $\mathrm{AlF}=3 \mathrm{I}$ & 0.08 & 3.84 & 3.01 & & & .0 & 739 & 10.22 \\
\hline & $A E F=4 N$ & 0.08 & 3.81 & 4.08 & & & .0 & 685 & 9.79 \\
\hline & $A I F=0 \mathrm{NO}$ & 0.07 & 2.50 & 0.00 & & & .8 & 590 & 0.22 \\
\hline & $\mathrm{AlF}=0 \quad \mathrm{NO} 3=3$ & 0.08 & 2.99 & 0.00 & & & .8 & 713 & 0.34 \\
\hline & $\mathrm{AlF}=0 \quad \mathrm{NO} 3=4$ & 0.11 & 4.01 & 0.00 & & & & 65 & .86 \\
\hline & $\mathrm{AIF}=0 \quad \mathrm{NO} 3=4.5$ & 0.12 & 4.51 & 0.00 & & & 8 & 87 & 1.48 \\
\hline & $\mathrm{AlF}=0 \quad \mathrm{NO} 3=5$ & 0.13 & 4.97 & 0.00 & & & & & .07 \\
\hline & $\mathrm{AlF}=0 \quad \mathrm{NO3}=5.6$ & 0.15 & 5.55 & 0.00 & & & 8 & & .19 \\
\hline & $\mathrm{AIF}=0 \mathrm{NO}=6$ & 0.16 & 6.01 & 0.00 & & & 8 & & .75 \\
\hline & $\mathrm{AlF}=0 \quad \mathrm{NO}=5$ & 0.13 & 4.97 & 0.00 & & & & & 2.05 \\
\hline & $\mathrm{AIF}=0.25 \mathrm{~N}$ & 0.13 & 4.97 & 0.27 & & & & 74 & 2.45 \\
\hline & $\mathrm{AIF}=0.5 \mathrm{NO}=5$ & 0.13 & 4.95 & 0.49 & & & & & 3.15 \\
\hline & AlF $=1 \mathrm{NC}$ & 0.13 & 5.01 & 1.01 & & & & & .17 \\
\hline & $\mathrm{AIF}=2 \mathrm{~N}$ & 0.12 & 5.04 & 1.99 & & & 8 & 1046 & 3.91 \\
\hline & $\mathrm{AIF}=3 \mathrm{~N}$ & 0.11 & 5.00 & 2.99 & & & .8 & 968 & 12.1 \\
\hline & $\mathrm{AlF}=4 \mathrm{~N}$ & 0.10 & 5.03 & 4.00 & & & .8 & 913 & 15.0 \\
\hline $5 \mathrm{~A}$ & $\operatorname{AlF}=0 \mathrm{~N}$ & 0.16 & 6.01 & 0.00 & & & 8 & 1457 & 5.4 \\
\hline $5 \mathrm{~B}$ & $\mathrm{AIF}=0.25$ & 0.16 & 5.97 & 0.26 & & & .8 & 1418 & 6.35 \\
\hline & $A \mid F=0.5$ & 0.15 & 5.93 & 0.52 & & & 8 & 1380 & 7.0 \\
\hline & $A \mid F=11$ & 0.15 & 5.98 & 1.0 & & & .8 & 1336 & 7.6 \\
\hline & AlF $=2 \mathrm{~N}$ & 0.14 & 6.0 & 1.9 & & & .8 & 1258 & 14.7 \\
\hline & $\mathrm{AIF}=3 \mathrm{~N}$ & 0.13 & 6.0 & 3.0 & & & & 1166 & 20.2 \\
\hline & AIF $=4 \mathrm{~N}$ & 0.12 & 5.9 & 4.0 & & & & 1088 & 18. \\
\hline & $A I F=0$ & 0.27 & 7.0 & 0.0 & & & & 1285 & 0.9 \\
\hline & $A \mid F=0.25$ & 0.26 & 7.0 & 0.2 & & & & 1250 & 9.0 \\
\hline & $\mathrm{AIF}=0.5$ & 0.25 & 6.9 & 0.5 & & & 8 & 1217 & 10.0 \\
\hline & $A \mid F=1 N$ & 0.25 & 6.9 & 0.7 & & & & 1178 & 10.5 \\
\hline & $\mathrm{AIF}=2 \mathrm{NC}$ & 0.2 & 7.0 & 0.95 & & & 0 & 1109 & 12.5 \\
\hline & AlF $=0 \mathrm{~N}$ & 0.16 & 4.0 & 0.00 & & & & 82 & 0.6 \\
\hline & AIF $=0.25 \mathrm{NO} 3=4$ & 0.16 & 3.9 & 0.27 & & & & 79 & 0.8 \\
\hline & AlF $=0.5 \mathrm{NO}=4$ & 0.15 & 3.9 & 0.5 & & & & 76 & 11 \\
\hline & $\mathrm{AIF}=1 \mathrm{NO}=4$ & 0.14 & 3.9 & 1.0 & & & & 71 & 1.8 \\
\hline & $\mathrm{AIF}=2 \mathrm{NO} 3=4$ & 0.12 & 3.84 & 1.99 & 486 & & & 63 & 5.0 \\
\hline $118 \mathrm{~F}$ & $\mathrm{AIF}=3 \mathrm{NO} 3=4$ & 0.11 & 3.79 & 3.02 & 486 & & 0.4 & 56 & 7.9 \\
\hline Pul18G & $\mathrm{AIF}=4 \mathrm{NO}=4$ & 0.10 & 3.74 & 4.00 & 486 & 17975 & 0.4 & 51 & 8.7 \\
\hline
\end{tabular}

process is expected to be low. Addition of ANN as a solution of $60 \%$ ANN to an Al:F ratio of 3 to 4 would both dilute the solution and contribute significant additional HLW. Since the dissolver solution was already at greater than $9 \mathrm{M}$ HNO3, operating the solvent extraction cycle at a higher than normal total nitrate held the potential to both keep the $\mathrm{Pu}$ concentration up and significantly improve the Pu extraction. A series of batch extraction tests (Pul10 through Pu118) were performed to investigate the effects of $\mathrm{Al}: \mathrm{F}$ ratio and total nitrate on the $\mathrm{Pu}$ extraction. Results from those tests are briefly summarized in the Table $V$ and illustrated in Figures 2 and 3. A more complete listing of the conditions and results are included in Table Al in the Appendix. The data shows the effect of $\mathrm{Al}: \mathrm{F}$ ratio and $\left[\mathrm{NO}_{3}{ }^{-}\right]_{\text {total }}$ on the $\mathrm{Pu} \mathrm{D} / \mathrm{a}$ in nitric acid solutions with $\mathrm{B}, \mathrm{Ca}$ and Fe present in solution. As expected, $\mathrm{Pu}$ extraction is enhanced both by the increase in Al:F ratio as well as increase $\left[\mathrm{NO}_{3}{ }^{-}\right]_{\text {cotal }}$. This is most likely due to shifts in the complexation of $\mathrm{Pu}-\mathrm{F}$ and $\mathrm{Pu}-\mathrm{NO}_{3}$. Complexation of $\mathrm{F}^{-}$by $\mathrm{Al}$ and $\mathrm{B}$ reduces the $F$ available to complex $\mathrm{Pu}$, however $\mathrm{B}$ is much less effective at complexing $\mathrm{F}^{-}$than $\mathrm{Al}$. Based on complexation constants obtained in the literature ${ }^{4}, \mathrm{Pu}$ is by far the best $F$ complexant present $\left(\log \mathrm{K}_{1}=6.77\right)$. Al is not as strong a complexant $\left(\log \mathrm{K}_{\mathrm{j}}=3.2\right.$ ), but with $\mathrm{Al} / \mathrm{Pu}>100$ and having the capacity to complex three $\mathrm{F}$ ions in significant amounts, Al effectively makes the $\mathrm{F}$ unavailable for $\mathrm{Pu}$ complexation. $B$ is only a fair $F$ complexation agent $\left(\log \mathrm{K}_{1}=1.4\right)$. Although $B$ can complex up to four $\mathrm{F}$ ions, the presence of $\mathrm{Al}$

effectively limits it to only one. Pu nitrate complexes are not as strong as any of the $\mathrm{F}$ complexes mentioned ( $\log \mathrm{K}_{1}=0.97$ ), however with 4 to $6 \mathrm{M}$ total nitrate present, mass action contributes to significant $\mathrm{Pu}$ nitrate complex formation. Calculations have been performed to attempt to quantify these effects and are summarized in the Table VI. Increasing the total nitrate or raising the $\mathrm{Al}: \mathrm{F}$ ratio both serve to shift $\mathrm{Pu}$ complexation in favor of nitrate complexes. This favors the extraction of $\mathrm{Pu}$ into ;BP. The neutral species, $\mathrm{Pu}\left(\mathrm{NO}_{3}\right)_{4}$, is believed to 


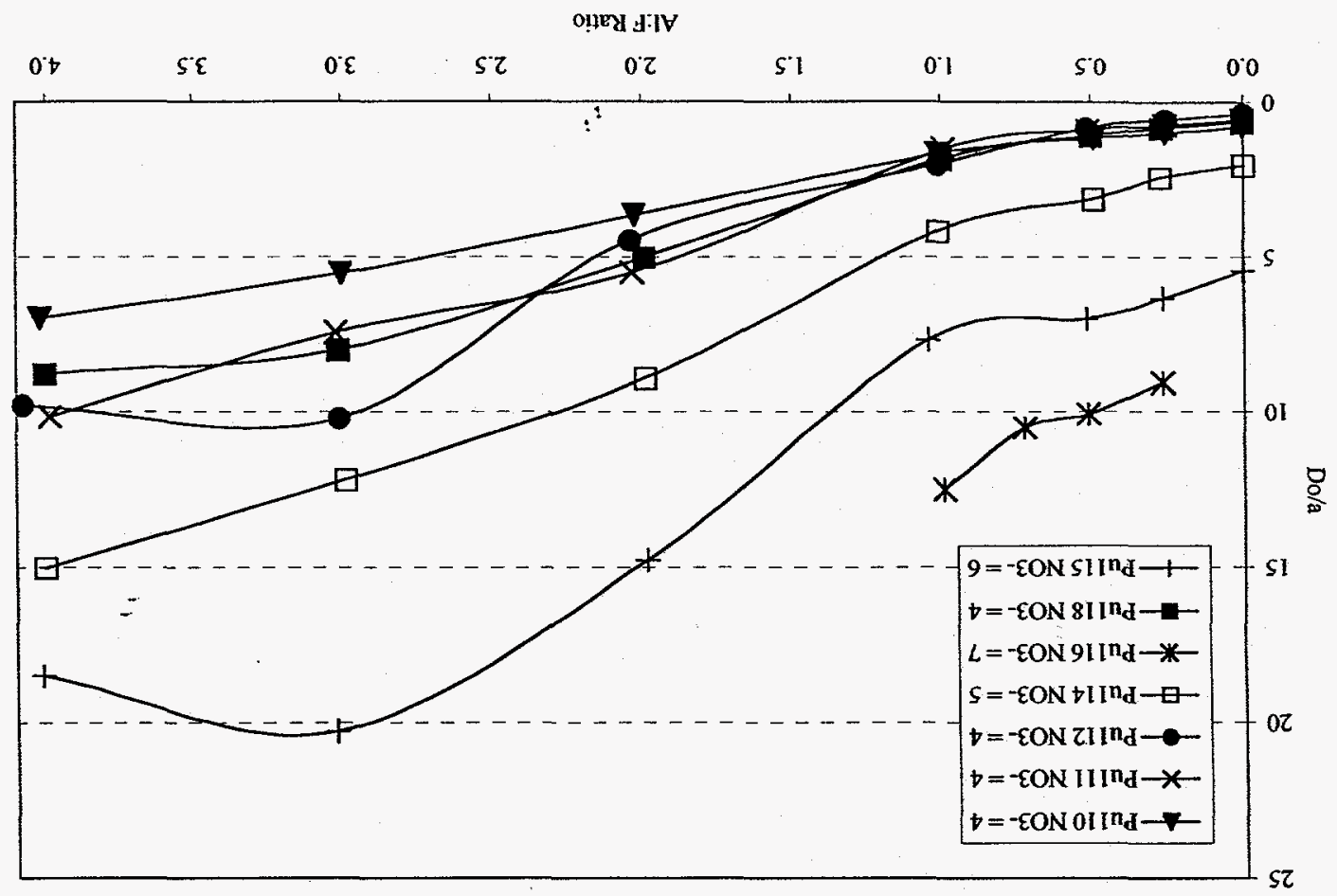

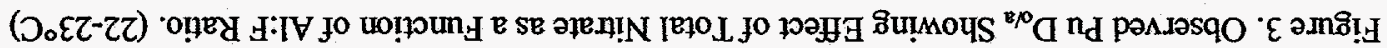

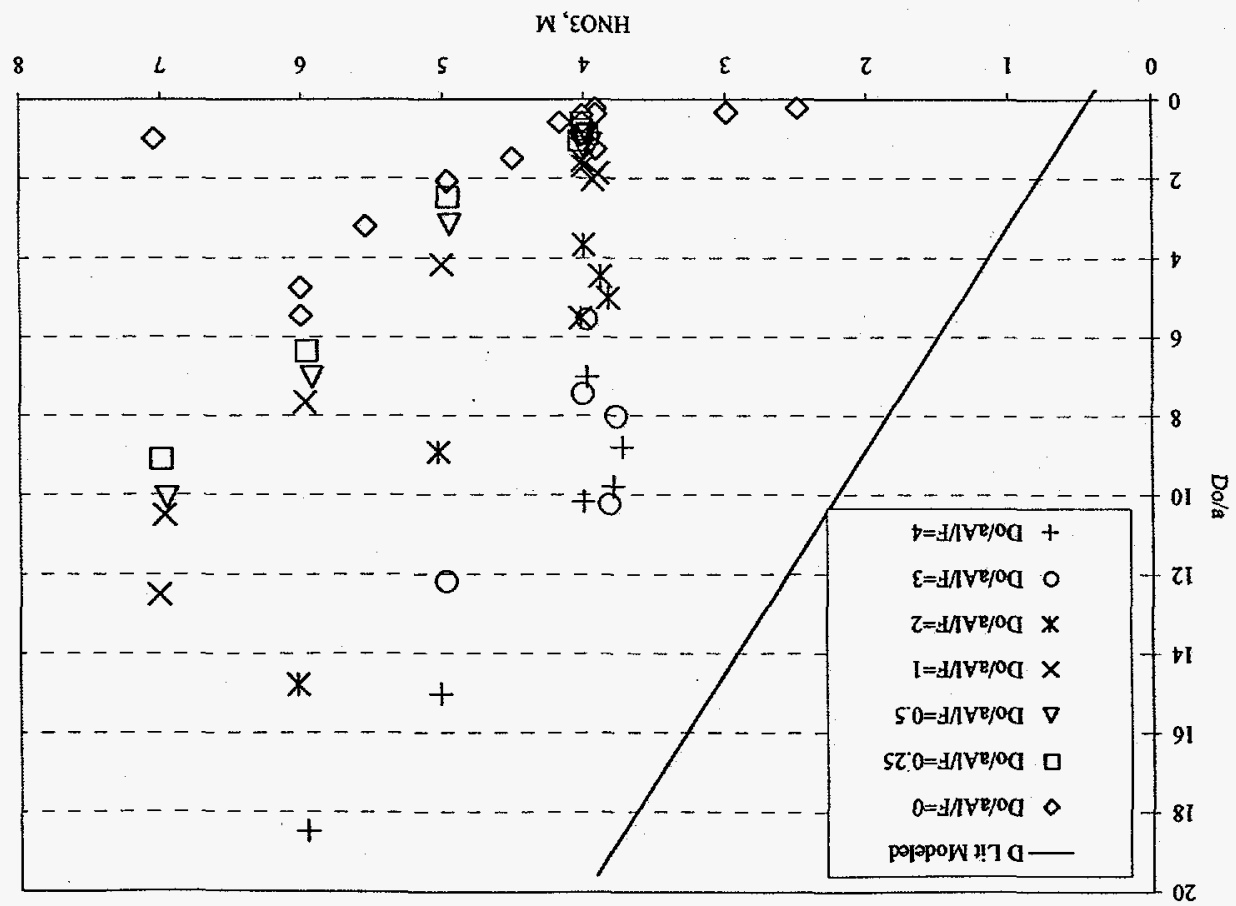

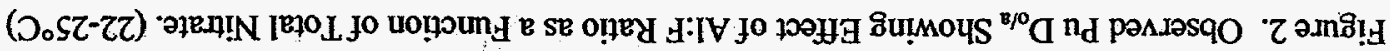


WSRC-TR-98-00121, Rev 0

Table VI. Pu-F and $\mathrm{Pu}-\mathrm{NO}_{3}{ }^{-}$Complexation Competition.

\begin{tabular}{lrrrrrrrr}
\hline \multicolumn{1}{c}{ Species, M } \\
\hline Pu, total & 0.002 & 0.002 & 0.002 & 0.002 & 0.002 & 0.002 & 0.002 & 0.002 \\
F, total & 0.25 & 0.25 & 0.25 & 0.25 & 0.25 & 0.25 & 0.25 & 0.25 \\
Al, total & 0 & 0 & 0 & 0.12 & 0.12 & 0.23 & 0.23 & 0.46 \\
B, total & 0 & 0.23 & 0.23 & 0.23 & 0.23 & 0.23 & 0.23 & 0.23 \\
HNO3, total & 4 & 4 & 6 & 4 & 6 & 4 & 6 & 4 \\
PuF 4 Pu $\left(\mathrm{NO}_{3}\right)_{\pi}{ }^{+4-x}$ & 3.61 & 1.13 & 0.47 & 0.27 & 0.11 & 0.10 & 0.04 & 0.03 \\
\hline
\end{tabular}

be the only extractable species. This is why the formation of Pu-nitrate complexes favors extraction. The mechanism is the conversion of other complexes to the neutral species as the neutral species is consumed from the aqueous phase by extraction with TBP.

The effect of temperature on the complexation equilibria was briefly investigated using the constants available for $\mathrm{F}, \mathrm{B}$, and $\mathrm{Al}$ complexation ${ }^{4}$. No information was located for the effect of temperature on $\mathrm{Pu}$

Table VII. Complexation Equations and Equilibrium Constants.

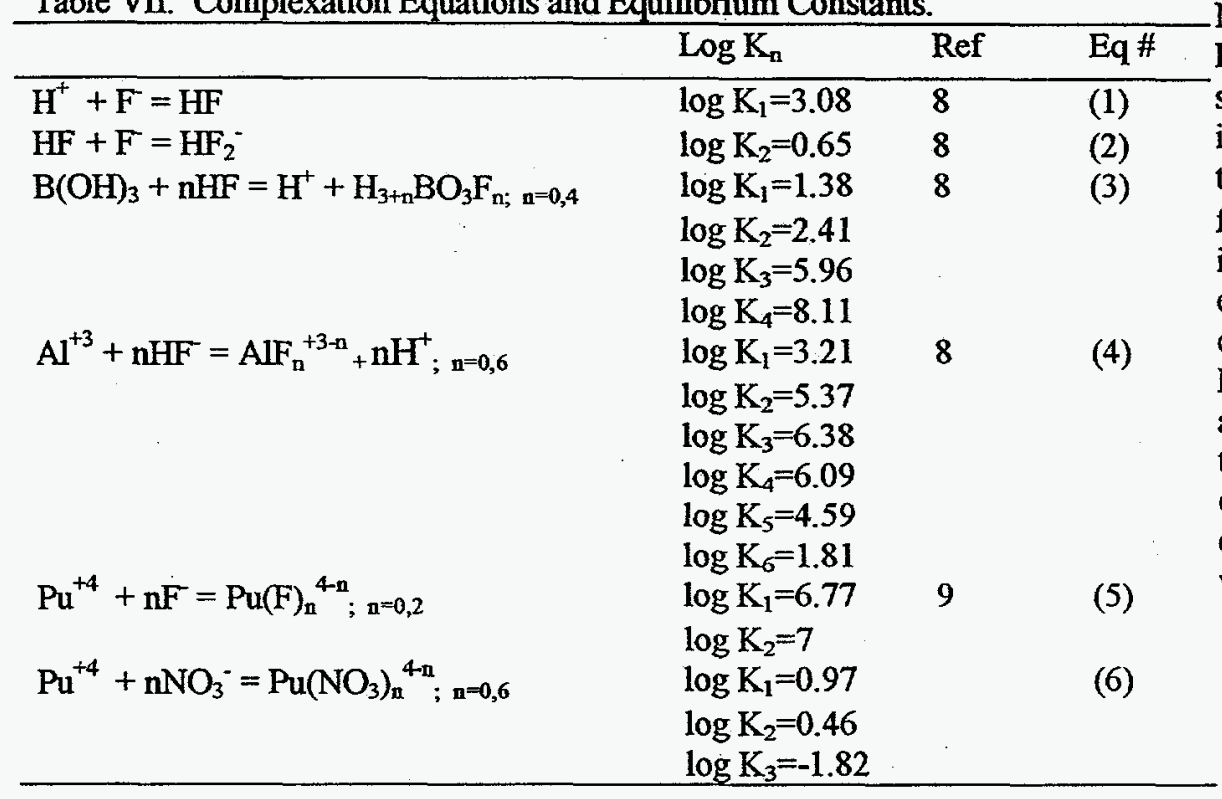
complexation with $\mathrm{F}$ or $\mathrm{NO}_{3}{ }^{-}$. Calculations with $\mathrm{F}$, $B$, and Al complexation showed a 10 percent increase in the free $F$ as the temperature was increased from 25 to $55^{\circ} \mathrm{C}$. The increase in free $F$ is estimated to cause a corresponding increase in $\mathrm{PuF}_{\mathrm{x}}{ }^{4-\mathrm{x}}$ complex formation and a resultant reduction in the $\mathrm{Pu} \mathrm{D}_{\mathrm{o} / \mathrm{a}}$. This may be offset by the general trend of $\mathrm{D}_{\mathrm{o} / \mathrm{a}}$ for $\mathrm{Pu}$ to increase with temperature.

Computer Simulation: Predicting how solvent extraction is affected requires process modeling. SEPHIS is not useful in this situation, as the program does not allow for modification of the $\mathrm{D}_{\mathrm{d} / \mathrm{a}}$. McKibben et $\mathrm{al}^{3}$ used the SOLVEX program to perform similar modeling for the effects of sulfate in the feed stream, but a working copy of the code was not located. (H-Canyon has since been found to be still using SOLVEX) As part of the development of the GTM, Argonne National Laboratory has developed a program that runs in an Excel environment as a macro. This program is called SASSE and allows the calculation of steady-state material balances for counter-current flow solvent-extraction processes with user input of appropriate values of $D_{0 / a}{ }^{6}$. McKibben et $\mathrm{al}^{3}$ performed a process sensitivity analysis on the PUREX process. That work showed that increases in the $2 \mathrm{AF}$ acidity both reduced $\mathrm{Pu}$ losses and reduced the $\mathrm{Pu}$ inventory in the process equipment. Modeling with SASSE was limited to effects on losses, impurity decontamination and acid scrubbing studies. Figure 4 shows A Bank results for a SASSE model. This model used values for the $\mathrm{HNO}_{3} \mathrm{D}_{\text {da }}$ in the scrub section of 0.14 to 0.22 for acid extraction and found the acid differed 0.11 percent between the normal $4 \mathrm{M}$ $\mathrm{HNO}_{3}$ and the proposed $6 \mathrm{M}$ total nitrate feed if all the nitrate was in the form of $\mathrm{HNO}_{3}$. Using a $\mathrm{D}_{\alpha \mathbf{a}}$ of 0.2 for $\mathrm{HF}$ and 0.08 for boric acid, DF's of 30 to 50 were calculated for the A Bank in a similar simulation. Some separation might be obtained in the B Bank, but this was not studied. Calculation of Pu losses was limited by the ability to predict both a realistic $D_{o / a}$ and stage efficiency that would be achieved in actual equipment.

Three conclusions were reached from the SASSE modeling that was performed:

1) Seven scrub stages will remove virtually all the acid, even with $6 \mathrm{M} \mathrm{HNO}_{3}$ in the feed.

2) At observed values of $D_{o / a}$ for $B$ or $F$, the $D F$ for $B$ and $F$ should be moderate.

3) With adjustment of the feed such that a $D_{\alpha / a}$ of 7 or greater is obtained in batch tests, the process losses should be on the order of 0.01 to 0.1 percent. 
Figure 4. Calculated Effect of Acid Scrubbing with 2AF Containing 6M HNO3.

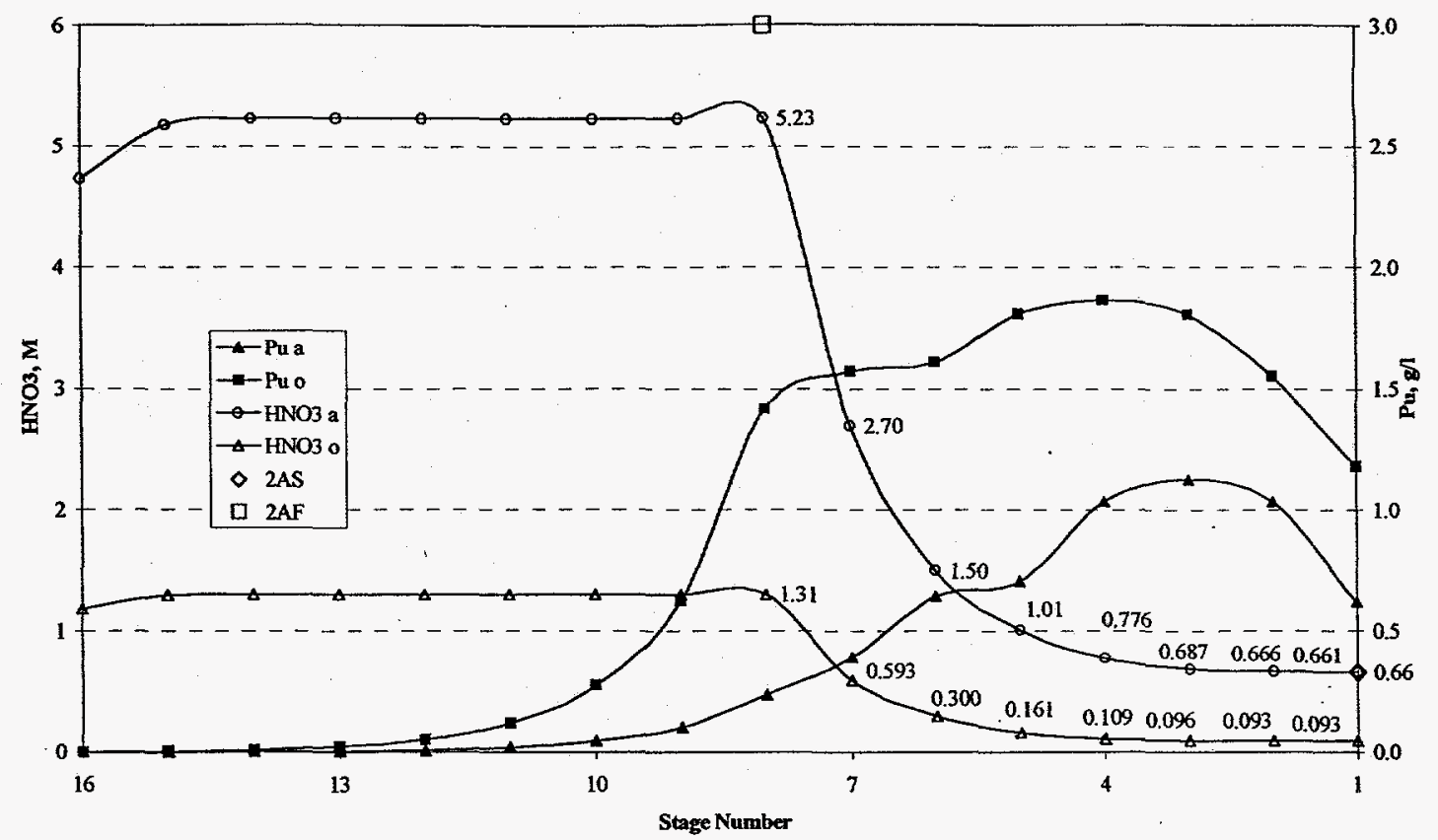

Minibank Experimental Conditions and Results: Two minibank experiments were performed for a comparative test of a proposed altered flowsheet with a historical flowsheet. The first run was made with a 4 $\mathrm{M} \mathrm{HNO}_{3} \mathrm{Pu}$ feed solution that contained $0.17 \mathrm{M}$ sulfate to simulate the base case for historical operation of the process. A second run with a $6 \mathrm{M} \mathrm{HNO}_{3} \mathrm{Pu}$ feed solution that contained high levels of $\mathrm{F}$ complexed $0.5: 1$ with

Table VIII. Feed Concentrations for the Minibank Runs.

\begin{tabular}{|c|c|c|c|c|c|c|c|c|c|c|c|c|}
\hline Description & gms & $\begin{array}{l}\text { Vol } \\
\text { ml }\end{array}$ & $\begin{array}{l}\mathrm{Pu} \\
\mathrm{g} / \mathrm{l}\end{array}$ & $\begin{array}{c}\text { HNO3 } \\
\text { M }\end{array}$ & $\begin{array}{l}\mathbf{F} \\
\mathbf{M}\end{array}$ & $\begin{array}{l}\mathbf{B} \\
\mathbf{M}\end{array}$ & $\begin{array}{l}\mathrm{Al} \\
\mathrm{M}\end{array}$ & $\begin{array}{l}\mathbf{P u} \\
\mathbf{M}\end{array}$ & $\begin{array}{c}\text { NO3 } \\
\mathrm{M}\end{array}$ & $\begin{array}{l}\mathrm{Fe} \\
\mathrm{g} / \mathrm{l}\end{array}$ & $\begin{array}{l}\mathrm{Ca} \\
\mathrm{M}\end{array}$ & $\begin{array}{c}\text { SO4 } \\
\text { M }\end{array}$ \\
\hline CR175PC1 & & 15 & 79.5 & 2.24 & & & & 0.333 & 3.57 & & & 0.000 \\
\hline $\mathrm{Na} 2 \mathrm{SO}_{4} * 10 \mathrm{H} 2 \mathrm{O}$ & 110 & & & & & & & & & & & \\
\hline Conc HNO3 & 717 & 505 & & 15.8 & & & & & 15.80 & & & \\
\hline DIH2O & 1425 & 1425 & & & & & & & & & & \\
\hline Minibank Run \#1 & 2268 & 2007 & 0.594 & 3.99 & & & & & 4.00 & & & 0.170 \\
\hline CR175PC1 & & 15 & 79.5 & 2.24 & & & & 0.333 & 3.57 & & & \\
\hline Ferric Nitrate $* 9 \mathrm{H} 2 \mathrm{O}$ & 22 & 9 & & & & & & & & & & \\
\hline Н3BO3 & 17 & & & & & & & & & & & \\
\hline $\mathrm{CaF} 2$ & 18 & & & & & & & & & & & \\
\hline DI $\mathrm{H}_{2} \mathrm{O}$ & 1234 & 1234 & & & & & & & & & & \\
\hline Cone HNO3 & 994 & 700 & & 15.8 & & & & & 15.80 & & & \\
\hline ANN Powder & 86 & 37 & & & & & & & & & & \\
\hline MiniBank Run \#2 & 2387 & 1995 & 0.598 & 5.97 & 0.231 & 0.138 & 0.116 & 0.003 & 6.00 & 1.52 & 0.116 & \\
\hline
\end{tabular}

Al was run as a proposed feedstock for an altered flowsheet. The details of the feed concentrations are shown in -Table VIII. Flowrates and concentrations of other streams are shown in Figure 5. Details of sampling points and flowrate

measurements are contained in appendix Table A3

Figures 6 and 7 show measured Pu concentration profiles for the 2A and 2B bank of each experiment. Figures 8 and 9 show a comparison of the $D_{o / a}$ for Pu in each bank. The main difference observed was in the $2 \mathrm{~A}$ bank on stage 6 . The concentrations appeared to be flat between stages 8 and 6 . This may have a sulfate complexation effect or a flow hydraulics problem, but neither has been confirmed. The $B$ bank showed no significant difference between the experiments. The 2BP-product solution was analyzed for $F$ contamination. This stream should have been absent the B or Al that was found to interfere an accurate analysis of the F. Total $\mathrm{F}$ was determined to be less than the detection limit of $10 \mathrm{ppm}$ in the 2BP-product solution. 
Figure 5. Solvent Extraction Flowsheet for Minibank Operation

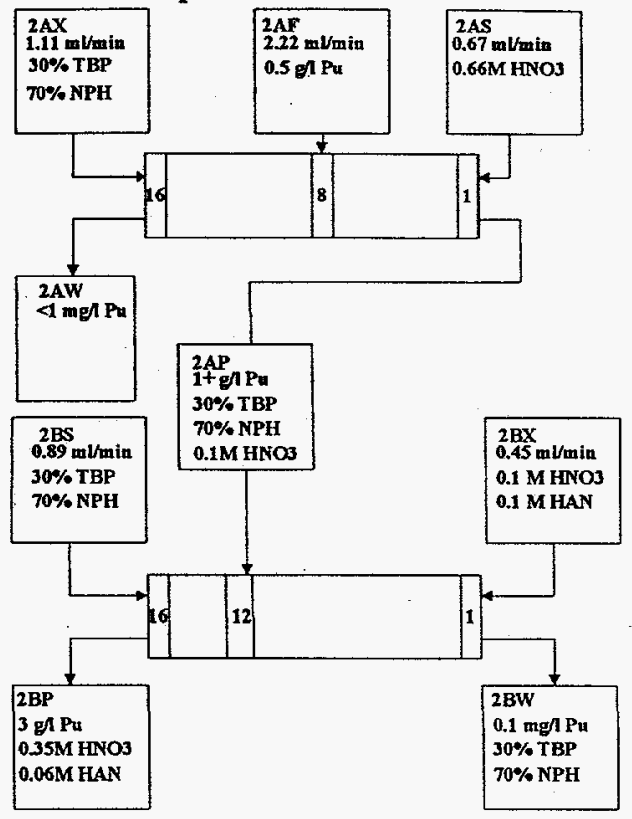

Table IX lists actual flowrates and shows material balances for each bank and the overall flowsheet. The 2AF Pu concentration was intended to be the same in both experiments, but the analytical results are different. The material balances for both banks and each bank individually are within experimental uncertainties. The total losses for both experiments differed in how much was lost to the $2 \mathrm{AW}$ versus the 2BW. The reason for the apparent increased losses to the 2BW in MB2 are not clear, however this result was observed with repeated samples and crosscontamination did not appear to be a mechanism. The $\mathrm{Pu} \mathrm{D}_{\mathrm{o} / \mathrm{a}}$ in stage 4 was a factor of 5 higher in MB2 than $\mathrm{MB} 1$, but was not significantly different on stages 4,6 , 8 or 10 (see Figure 9). This is similar to effects observed when DBP levels in the solvent prevent complete stripping. The solvent was carbonate washed between the two experiments. Possibly this was not complete. Contamination of the solvent with an epoxy used on the $2 \mathrm{AX}$ feed container used in the first experiment did occur, however that problem should have affected both experiments similarly. There is no direct evidence that supports that any component in the $2 \mathrm{AF}$ was responsible for this result. However it is

prudent to be especially observant for any unusual losses to either the $2 \mathrm{AW}$ or $2 \mathrm{BW}$ whenever a major flowsheet change is implemented.

Table IX. Flowrates, Pu Material Balance and Losses for Minibank Runs. $\left(25-27^{\circ} \mathrm{C}\right)$

\begin{tabular}{|c|c|c|c|c|c|c|c|c|c|c|c|}
\hline Run & & $\begin{array}{c}2 \mathrm{AF} 2 \mathrm{AX} \\
\mathrm{ml} / \mathrm{min}\end{array}$ & $2 \mathrm{AS}$ & $2 \mathrm{AW}^{*}$ & $2 \mathrm{AP}^{*}$ & $\overline{2 B X}$ & $2 \mathrm{BS}$ & $2 \mathrm{BW}^{*}$ & $\overrightarrow{2 \mathrm{BP}^{2}}$ & & \\
\hline & Target Rate & $\begin{array}{ll}2.22 & 1.11\end{array}$ & 0.67 & 2.89 & 1.11 & 0.45 & 0.89 & 2.00 & 0.45 & & \\
\hline MBI & Measured Rate & 2.17 & 0.67 & 2.84 & 1.16 & 0.47 & 0.92 & 2.08 & 0.47 & & \\
\hline MB2 & Measured Rate & $\begin{array}{cc}2.09 & 1.19 \\
\mathrm{Pu} & \\
\mathrm{g} / \mathrm{l} & \end{array}$ & 0.65 & 2.73 & 1.19 & 0.47 & 0.94 & 2.13 & 0.47 & & \\
\hline MB1 & & 0.66 & & 0.0008 & 1.18 & & & 0.0001 & 3.13 & & \\
\hline MB2 & & $\begin{array}{l}0.76 \\
\mathrm{Pu}, \mathrm{mg} / \mathrm{min}\end{array}$ & & 0.0005 & 1.28 & & & 0.0006 & 2.99 & Material & Balance \\
\hline MB1 & Both Banks & 1.43 & & & & & & 0.0002 & 1.47 & -0.03 & $-2.4 \%$ \\
\hline MB2 & Both Banks & 1.59 & & & & & & 0.0014 & 1.41 & 0.17 & $10.9 \%$ \\
\hline MB1 & A Bank & 1.43 & & 0.0022 & 1.37 & & & & & 0.06 & $4.4 \%$ \\
\hline $\mathrm{MB2}$ & A Bank & 1.59 & & 0.0013 & 1.53 & & & & & 0.06 & $3.7 \%$ \\
\hline MB1 & B Bank & & & & 1.37 & & & 0.0002 & 1.47 & 0.06 & $4.2 \%$ \\
\hline $\mathrm{MB2}$ & $\begin{array}{c}\text { B Bank } \\
\text { Total }\end{array}$ & Losses, \% & & & 1.53 & & & 0.0014 & 1.41 & 0.11 & $7.5 \%$ \\
\hline$\overline{\text { MB1 }}$ & $0.17 \%$ & & & $0.15 \%$ & & & & $0.02 \%$ & & & \\
\hline MB2 & $0.17 \%$ & & & $0.08 \%$ & & & & $0.09 \%$ & & & \\
\hline
\end{tabular}

Uncertainies: There are both experimental and calculational uncertainties throughout this work that can affect the conclusions of this work. These were constantly evaluated during the course of this work to minimize the effect on the most important results.

Sample dilution error of less than 5 percent would be expected due to the accuracy of the pipets. Technician error on an individual dilution sometimes results in much larger errors. Such errors probably occur more often with radioactive samples due to awkward working conditions. Obviously inconsistent data points in the Radscreen analyses were routinely reanalyzed and when necessary the test repeated, until a Pu alpha value was obtained that appeared to be consistent with the other data points. Organic samples were found to be 
somewhat more difficult to accurately pipet based on the number of samples where inconsistencies were observed. Counting errors are generally minor contributors to the total analytical uncertainty.

The wet chemistry methods of Free Acid and F by ISE were used only to a limited degree. The complex solution matrix had earlier been shown to cause a low bias in the F by ISE method ${ }^{2}$. The ability of the Free Acid method to handle the complex solution matrix was not validated and thus was not relied on heavily in this work. Most solutions were made up gravimetrically based on estimated densities of the final solution. The solution density for these solutions was primarily determined by the nitric acid and $\mathrm{Al}\left(\mathrm{NO}_{3}\right)_{3}$ concentrations and the uncertainties in the estimated density are probably only about 1 percent.

All experimental work was performed at laboratory ambient conditions that ranged form 22 to $27^{\circ} \mathrm{C}$ whereas the plant process will run at 40 to $50^{\circ} \mathrm{C}$. The literature indicates that the free $\mathrm{F}$ should increase slightly ${ }^{8}$ (which should reduce the $\mathrm{Pu} \mathrm{D}_{\mathrm{or} / \mathrm{a}}$ ) while the general trend would be for a small increase in the $\mathrm{Pu} \mathrm{D}_{\mathrm{os}}{ }^{3}$. Overall the temperature is expected to have only a small influence on the $\mathrm{Pu} \mathrm{D}_{\alpha_{\mathrm{a}}}$ based on the limited available data, however the complex solution matrix involved makes this expectation relatively weak and there are no experimental data to verify the magnitude of the effect.

Cross contamination of the samples was generally not believed to be a significant problem. Where this type of problem was most likely to affect results would have been when there was a large difference between the alpha activity of samples that were physically nearby and the lower sample was contaminated. This would have had the greatest impact on the batch extraction tests and would have lower the measured $\mathrm{Pu} \mathrm{D}_{\text {ola. }}$. Modest inconsistencies ( 20 to 30 percent) were observed between some data values that could have been due to this or small sample dilution errors. The number of data points taken reduces the impact of 20 to 30 percent errors that may have occurred on an isolated data point.

A limited effort was put into modeling and computer simulation of the minibank experiment. The results from those simulations have a limited value due to several effects that were not modeled. As discussed earlier, temperature effects on the $\mathrm{D}_{\mathrm{o} / \mathrm{a}}$ and complexation were not included due to the limited data available. This combined with the uncertainty in the relative values of $\mathrm{D}_{\mathrm{o} / \mathrm{a}}$ for $\mathrm{F}$ compared with $\mathrm{Al}$ and $\mathrm{B}$ in stages 5,6 and 7 of the scrub section of the $2 \mathrm{~A}$ Bank, leaves a lot of uncertainty in the Pu concentration profile in the scrub section. The large effect of $\mathrm{F}$ on the extraction of $\mathrm{Pu}$ could be significant under conditions where $\mathrm{Al}$ is scrubbed better than $\mathrm{F}$. The minibank experiment showed this did not occur with the operating conditions tested at room temperature, but some complexation and extraction changes have to be expected for a $20^{\circ} \mathrm{C}$ operating temperature change. 
Figure 6. 2A Bank Concentration Profiles from Minibank Experiments.

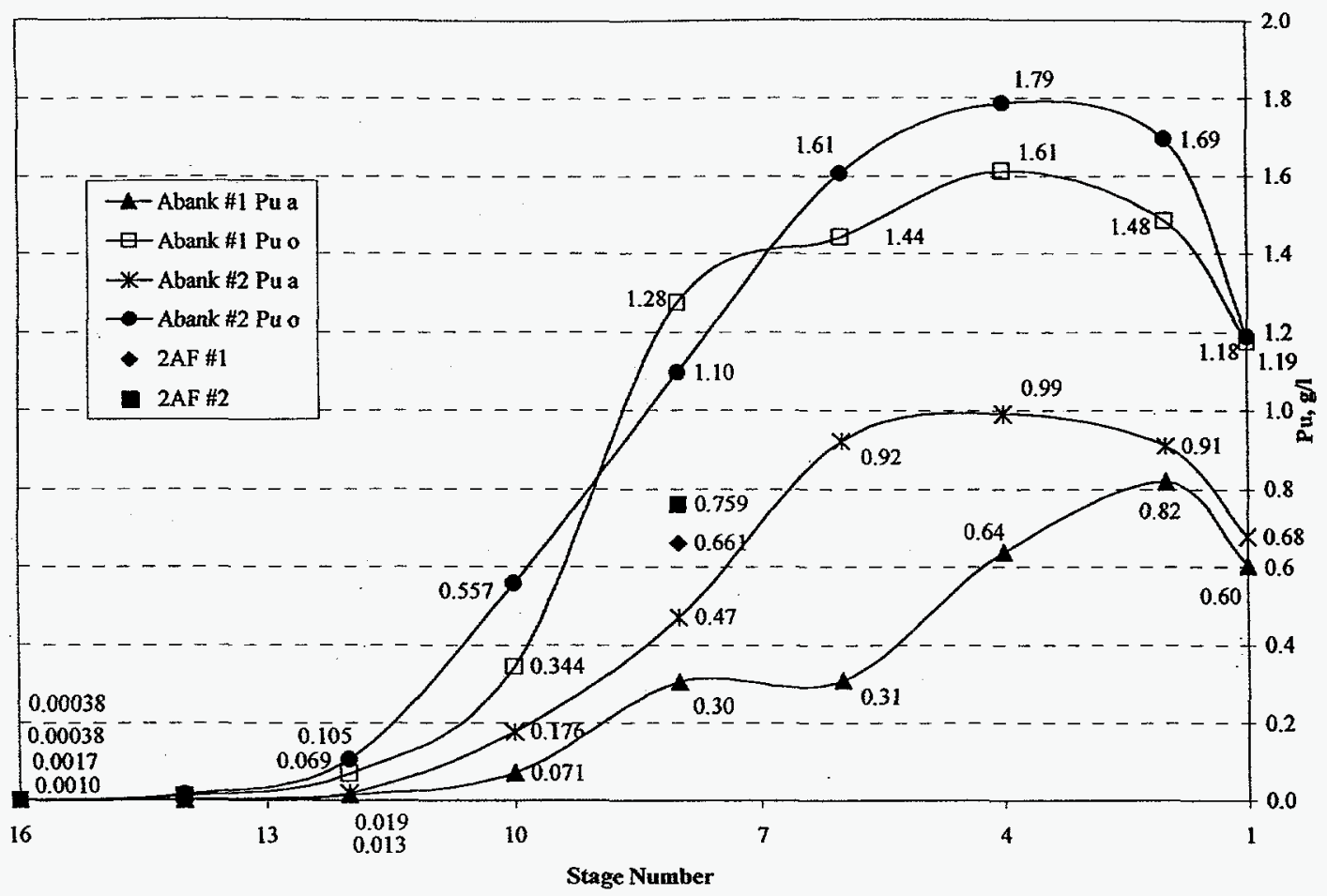

Figure 7. 2B Bank Concentration Profiles from Minibank Experiments.

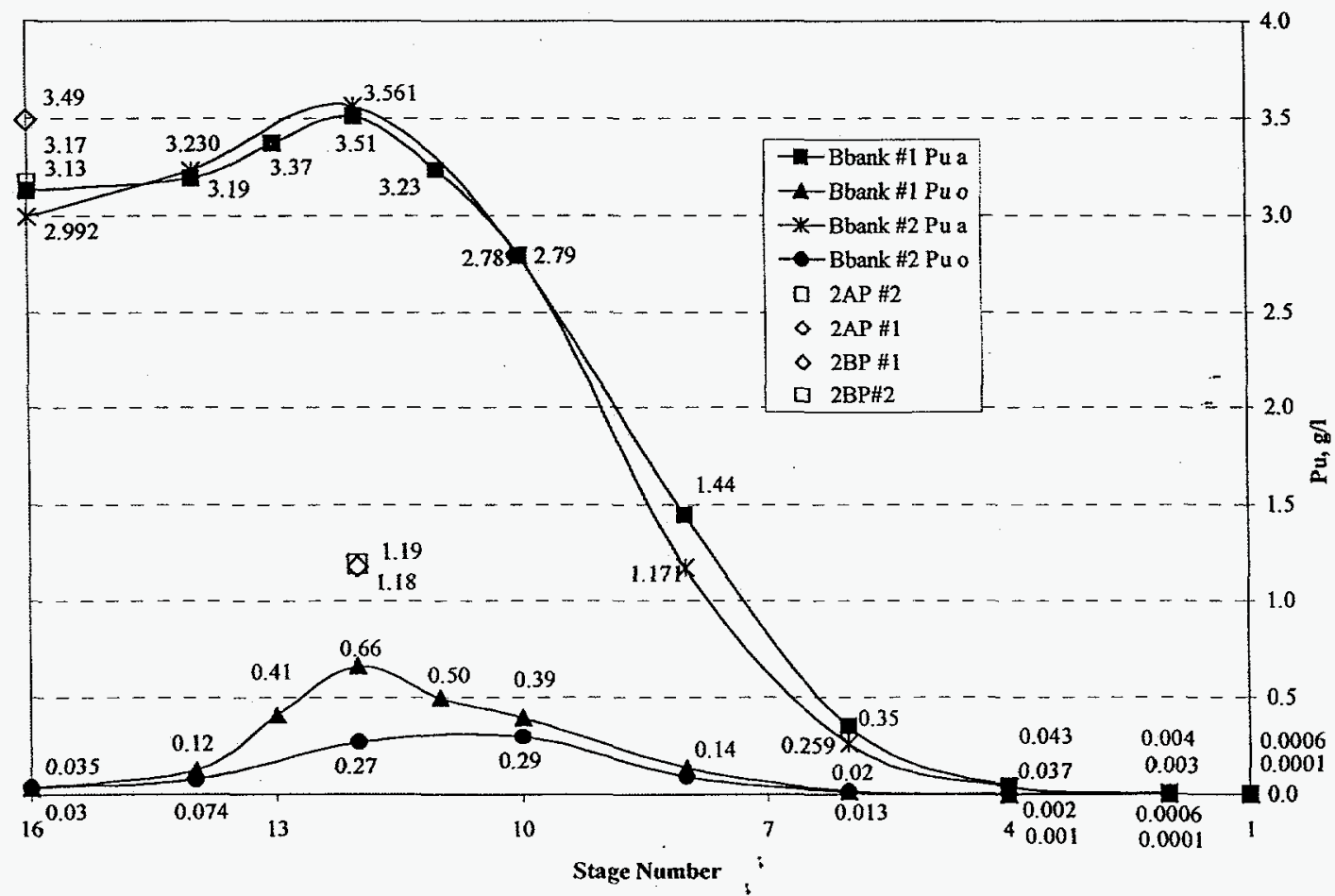


Figure 8. Observed 2A Bank Pu $D_{o / a}$ from Minibank Experiments.

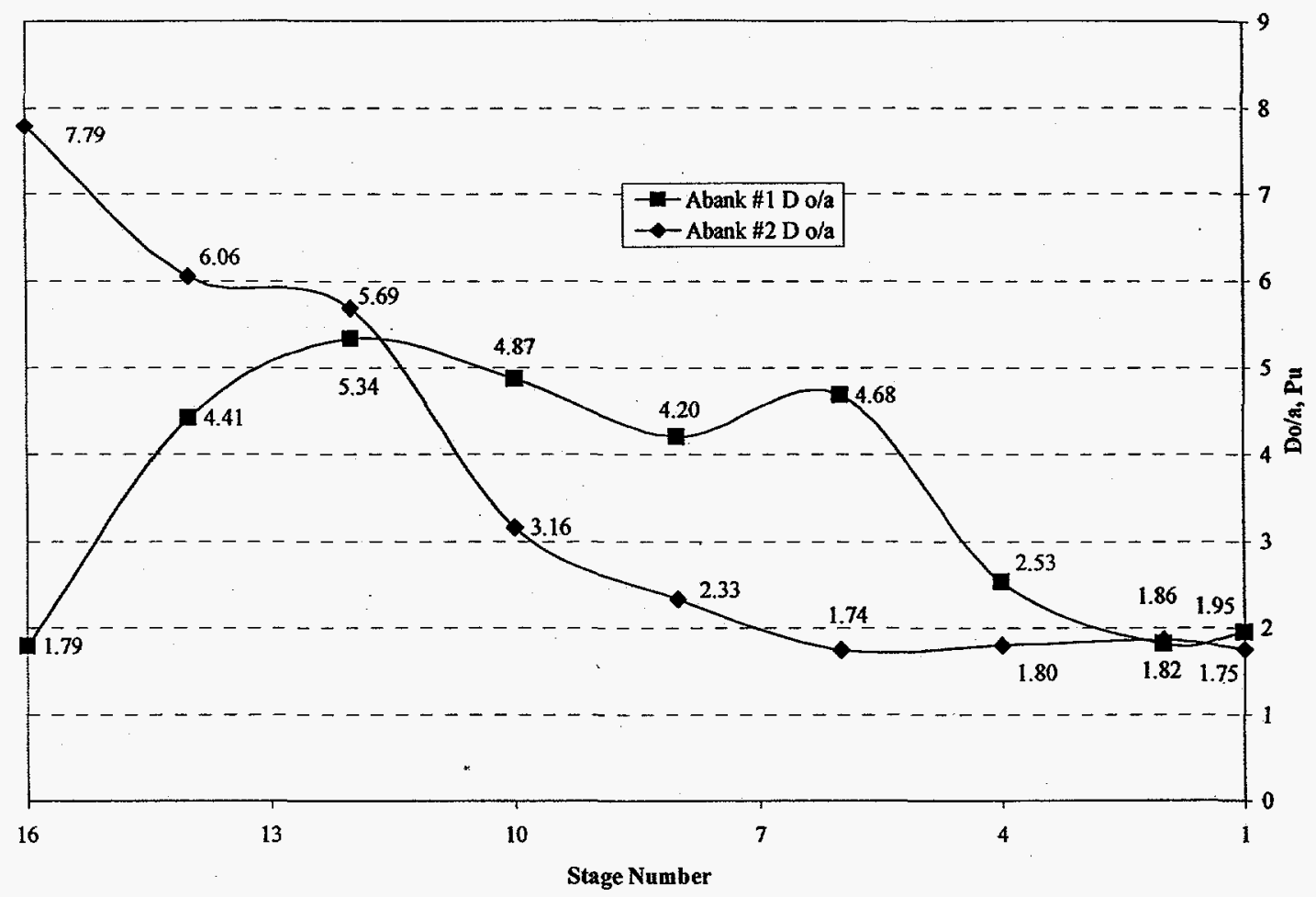

Figure 9. Observed 2B Bank Pu $D_{\alpha / a}$ from Minibank Experiments.

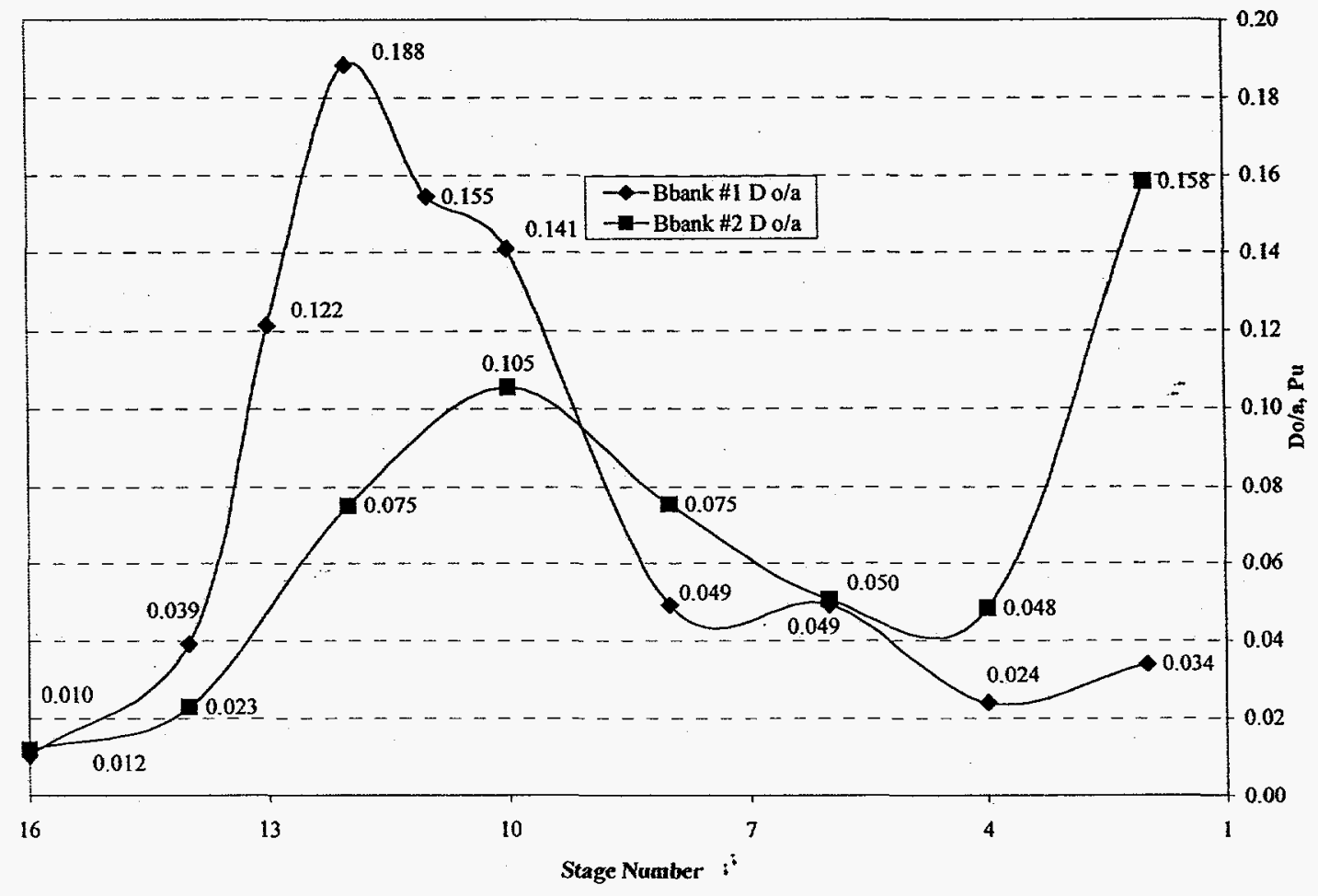




\section{References}

1. J. H. Gray, D. G. Karraker, T. S. Rudisill, and G. T. Chandler, "Dissolution of Sand, Slag, and Crucible Residues in the F-Canyon Dissolvers," WSRC-TR-97-00367, Westinghouse Savannah River Company, Aiken, SC (December 1997).

2. D. G. Karraker, J. H. Gray, T. S. Rudisill, R. R. Livingston, F. R. Graham, E. A. Kyser III, A. M. Murray, R. A. Pierce, J. I. Mickalonis, and D. B. Allen, "Flowsheet Modifications for Dissolution of Sand, Slag, and Crucible Residues in the F-Canyon Dissolvers," WSRC-TR-97-00395, Westinghouse Savannah River Company, Aiken, SC (December 1997).

3. J. M. McKibben, T. G. Campbell, C. T. Barker, and J. S. Gramling "Computer Simulations of the SRP Purex Process.” DPSPU 78-11-24, E. I. Du Pont de Nemours \& Co, Savannah River Plant, Aiken, SC (January, 1979).

4. Science and Technology of Tributyl Phosphate, Volume IV: Extraction of Water and Acids, Supplement to Volume IV : Tabulated Data for Extraction of Inorganic Acids by TBP, W. W. Schulz, J. D. Navratil, A.S. Kertes, Editors, CRC Press, 1991.

5. G.Petrich, Z. Kolarik, "The 1981 Purex Distribution Data Index", KfK 3080 PWA 94/80, Institut Fur Heisse Chemie Projekt Wiederaufarbeitung und Abfallbehandlung, Karlstuhe, January, 1981

6. R. A. Leonard, M. C. Regalbuto, “A Spreadsheet Algorithm for Stagewise Solvent Extraction", Sol. Extr. and Ion Exch., 12(5), 909-930, (1994)

7. Science and Technology of Tributyl Phosphate, Volume I: Synthesis, Properties, Reactions and Analysis", W. W. Schulz, J. D. Navratil, A.S. Taalbot, Editors, CRC Press, 1984, pg 179.

8 P.A. Anderson, J. D. Christian, "Alternative Reagent to Mercuric Nitrate Catalyst for Dissolution of Aluminum-Clad Nuclear Fuels in Nitric Acid," Journal of Materials Research, Vol 13, No 1, Jan 1998, pg 68-76

9. R. M. Smith and A. E. Martel, Critical Stability Constants, Volume 4: Inorganic Complexes, Plenum Press, New York, NY (1976).

10. "Gmelin Handbuch der Anorganishchen Chemie, Band 21, Transurane, Teil D1: Chemie in Losung," Gunter Koch, Karl-Christian Buschbeck, Springer-Verlag, New York, 1975. 
WSRC-TR-98-00121, Rev 0

Table A1. Experimental Conditions and Results from Batch Extraction Tests.

\begin{tabular}{|c|c|c|c|c|c|c|c|c|c|c|c|c|c|c|c|c|c|c|}
\hline $\begin{array}{c}\text { Sample } \\
\text { ID }\end{array}$ & & $\begin{array}{l}\mathbf{H}+ \\
\mathbf{M}\end{array}$ & $\begin{array}{l}\mathbf{F} \\
\mathbf{M}\end{array}$ & $\begin{array}{l}\text { B } \\
\text { M }\end{array}$ & $\begin{array}{l}\text { Al } \\
\text { M }\end{array}$ & $\begin{array}{c}\mathrm{Pu} \\
\mathrm{mM}\end{array}$ & $\begin{array}{c}\text { NO3- } \\
\mathrm{M}\end{array}$ & $\begin{array}{l}\mathrm{Fe} \\
\mathrm{g} / 1 \\
\end{array}$ & $\begin{array}{l}\mathrm{Ca} \\
\mathrm{M} \\
\end{array}$ & Al:F & $\mathrm{F}: \mathrm{Pu}$ & NO3:Pu & B:F & $\begin{array}{l}\mathrm{Am} 241 \\
\mathrm{uCi} / \mathrm{ml}\end{array}$ & $\begin{array}{c}\mathrm{Pu} \\
\mathbf{u C i} / \mathrm{ml} \\
\end{array}$ & $\begin{array}{c}\mathrm{Pu} \\
\mathrm{mg} /\end{array}$ & $\begin{array}{c}\text { D } \\
\text { O/A }\end{array}$ & $\begin{array}{c}\text { Mat'I } \\
\mathrm{Bal}\end{array}$ \\
\hline Pul08A & AEA & 4.1 & 0.162 & 0.07 & 0.00 & 2.7 & 3.92 & 0.7 & 0.08 & 0.00 & 60 & 1442 & 0.4 & 0.506 & 43.0 & 596 & 0.22 & $100 \%$ \\
\hline Pu108B & & 4.1 & 0.081 & 0.07 & 0.00 & 2.7 & 3.92 & 0.7 & 0.04 & 0.00 & 30 & & 0.8 & 0.429 & 37.9 & 526 & 0.38 & $100 \%$ \\
\hline Puil08C & CEA & 4.1 & 0.016 & 0.07 & 0.00 & 2.7 & 3.92 & 0.7 & 0.01 & 0.00 & 6 & 1442 & 4.0 & 0.353 & 24.8 & 344 & 1.26 & $107 \%$ \\
\hline Pul08D & DEA & 4.1 & 0.017 & 0.00 & 0.00 & 2.9 & 4.18 & 0.7 & 0.01 & 0.00 & 6 & 1440 & 0.0 & & 33.3 & 462 & 0.59 & $101 \%$ \\
\hline Pul10A & $\mathrm{AlF}=0 \quad \mathrm{NO} 3=4$ & 4.2 & 0.11 & 0.08 & 0.00 & 3.8 & 4.01 & 1.0 & 0.05 & 0.00 & 29 & 1067 & 0.8 & & 66.5 & 923 & 0.80 & $100 \%$ \\
\hline Pul10B & $\mathrm{AlF}=0.25 \mathrm{NO} 3=4$ & 4.2 & 0.11 & 0.08 & 0.03 & 3.7 & 4.04 & 1.0 & 0.05 & 0.25 & 29 & 1089 & 0.8 & & 65.3 & 907 & 1.02 & $99 \%$ \\
\hline Pul10C & $\mathrm{AlF}=0.5 \mathrm{NO}$ & 4.0 & 0.1 & 0.08 & 0.05 & 3.6 & 4.01 & 0.9 & 0.05 & 0.49 & 29 & 1110 & 0.8 & 37 & 63.3 & 879 & 1.19 & $101 \%$ \\
\hline Pul10D & $A \mid F=1 \mathrm{NO}$ & 3.9 & 0.1 & 0.08 & 0.10 & 3.5 & 4.01 & 0.9 & 0.05 & 1.01 & 29 & 1156 & 0.8 & 12 & 60.4 & 838 & 1.69 & $97 \%$ \\
\hline Pul10E & $\mathrm{AIF}=\mathbf{2} \mathrm{NO}$ & 3.6 & 0.09 & 0.07 & 0.19 & 3.2 & 4.01 & 0.8 & 0.05 & 2.03 & 29 & 1245 & 0.8 & 169 & 55.3 & 767 & 3.66 & $15 \%$ \\
\hline Pu110F & $\mathrm{AlF}=3 \mathrm{NO}$ & 3.4 & 0.09 & 0.07 & 0.26 & 3.0 & 3.99 & 0.8 & 0.04 & 3.00 & 29 & 1331 & 0.8 & 432 & 51.0 & 707 & 5.54 & $96 \%$ \\
\hline 10G & $\mathrm{AlF}=4 \mathrm{NC}$ & 3.2 & 0.08 & 0.06 & 0.32 & 2.8 & 3.99 & 0.7 & 0.04 & 4.02 & 29 & 1420 & 0.8 & 0.401 & 47.3 & 656 & 7.00 & $6 \%$ \\
\hline Pullla & $\mathrm{AIF}=0 \mathrm{NC}$ & 4.2 & 0.15 & 0.07 & 0.00 & 3.8 & 4.01 & 1.0 & 0.07 & 0.00 & 39 & 1067 & 0.5 & 0.643 & 70.0 & 971 & 0.58 & $9 \%$ \\
\hline $1 \mathrm{~B}$ & $\mathrm{AIF}=0.25 \mathrm{~N}$ & 4.1 & 0.14 & 0.07 & 0.04 & 3.7 & 4.02 & 1.0 & 0.07 & 0.25 & 39 & 1098 & 0.5 & 632 & 68.7 & 954 & 0.75 & $6 \%$ \\
\hline Pu111C & $\mathrm{AIF}=0.5 \mathrm{~N}$ & 3.9 & 0.14 & 0.06 & 0.07 & 3.6 & 4.02 & 0.9 & 0.07 & 0.51 & $39^{\circ}$ & 1129 & 0.5 & 512 & 66.6 & 924 & 0.92 & $6 \%$ \\
\hline Pul11D & $A \mid F=1$ & 3.8 & 0.13 & 0.06 & 0.13 & 3.4 & 4.01 & 0.9 & 0.07 & 0.99 & 39 & 1187 & 0.5 & 84 & 63.5 & 881 & 1.54 & $3 \%$ \\
\hline $11 E$ & AIF $=2 \mathrm{I}$ & 3.4 & 0.12 & 0.06 & 0.25 & 3.1 & 4.03 & 0.8 & 0.06 & 2.03 & 39 & 1313 & 0.5 & 34 & 58.2 & 807 & 5.52 & $101 \%$ \\
\hline Pull1F & AlF $=3 \mathrm{~N}$ & 3.1 & 0.11 & 0.05 & 0.33 & 2.8 & 4.03 & 0.7 & 0.06 & 3.02 & 39 & 433 & 0.5 & 493 & 53.6 & 744 & 7.43 & $3 \%$ \\
\hline 10 & $\mathrm{AIF}=4 \mathrm{NC}$ & 2.9 & 0.1 & 0.05 & 0.41 & 2.6 & 4.02 & 0.7 & 0.05 & 3.99 & 39 & 49 & 0.5 & 157 & 49.7 & 690 & 10.16 & $7 \%$ \\
\hline $12 \mathrm{~A}$ & $\mathrm{AIF}=0 \mathrm{NO} 3$ & 4.0 & 0.11 & 0.00 & 0.00 & 3.8 & 4.01 & 1.0 & 0.05 & 0.00 & 29 & 1067 & 0.0 & 90 & 69.5 & 965 & 0.40 & $103 \%$ \\
\hline $12 B$ & AlF $=0.25 \mathrm{~N}$ & 3.9 & 0.11 & 0.00 & 0.03 & 3.7 & 4.02 & 0.9 & 0.05 & 0.25 & 29 & 1089 & 0.0 & 579 & 68.3 & 947 & 0.58 & $101 \%$ \\
\hline $12 \mathrm{C}$ & $\mathrm{AIF}=0.5 \mathrm{NC}$ & 3.8 & 0.1 & 0.00 & 0.05 & 3.6 & 3.98 & 0.9 & 0.05 & 0.51 & 2 & 12 & 0.0 & 361 & 66.2 & 918 & 0.87 & $100 \%$ \\
\hline 2D & $A I F=1 \mathrm{NO}$ & 3.6 & 0.1 & 0.00 & 0.10 & 3.4 & 3.95 & 0.9 & 0.05 & 1.01 & 2 & & 0.0 & & 63.1 & 875 & 2.03 & $96 \%$ \\
\hline $2 \mathrm{E}$ & $\mathrm{AIF}=$ & 3.3 & 0.09 & 0.00 & 0.18 & 3.1 & 3.89 & 0.8 & 0.04 & 2.04 & 2 & 46 & 0.0 & 190 & 57.8 & 801 & 4.45 & $66 \%$ \\
\hline $12 \mathrm{~F}$ & $\mathrm{AlF}=3 \mathrm{NC}$ & 3.1 & 0.08 & 0.00 & 0.25 & 2.9 & 3.84 & 0.7 & 0.04 & 3.01 & 25 & & 0.0 & 51 & 53.2 & 739 & 10.22 & $104 \%$ \\
\hline $2 \mathrm{G}$ & AIF $=4 \mathrm{NO} 3$ & 2.8 & 0.08 & 0.00 & 0.31 & 2.7 & 3.81 & 0.7 & 0.04 & 4.08 & 2 & 26 & 0.0 & 419 & 49.4 & 685. & 9.79 & $95 \%$ \\
\hline $13 \mathrm{~A}$ & AIF $=0 \quad N O 3=2.5$ & 2.6 & 0.07 & 0.05 & 0.00 & 2.3 & 2.50 & 0.6 & 0.03 & 0.00 & 29 & 084 & 0.8 & 361 & 42.6 & $590^{\circ}$ & 0.22 & $101 \%$ \\
\hline $13 B$ & $A I F=0 N C$ & 3.1 & 0.08 & 0.06 & 0.00 & 2.8 & 2.99 & 0.7 & 0.04 & 0.00 & 2 & & 0.8 & 436 & 51.4 & 713 & 0.34 & $102 \%$ \\
\hline $13 \mathrm{C}$ & $\mathbf{A I F}=\mathbf{0} \mathbf{N}$ & 4.2 & 0.11 & 0.09 & 0.00 & 3.8 & 4.01 & 1.0 & 0.05 & 0.00 & 2 & & 0.8 & 590 & 69.5 & 965 & 0.86 & $95 \%$ \\
\hline & $A \mid F=0 \quad N C$ & 4.7 & 0.12 & 0.10 & 0.00 & 4.2 & 4.51 & 1.1 & 0.06 & 0.00 & & & 0.8 & 664 & 78.3 & 1087 & 1.48 & $100 \%$ \\
\hline & AIF $=0 \mathrm{~N}$ & 5.2 & 0.13 & 0.11 & 0.00 & 4.7 & 4.97 & 1.2 & 0.07 & 0.00 & & & 0.8 & 734 & 86.6 & 1201 & 2.07 & $95 \%$ \\
\hline & $\mathrm{AIF}=0 \mathrm{NO}$ & 5.8 & 0.15 & 0.12 & 0.0 & 5.2 & 5.55 & 1.4 & 0.08 & 0.00 & & & 0.8 & & 96.8 & 1343 & 3.19 & $97 \%$ \\
\hline & AIF $=$ & 6.3 & 0.16 & 0.13 & 0.0 & 5.7 & 6.01 & 1.5 & 0.08 & 0.00 & 2 & & 0.8 & 891 & 105.0 & 1457 & 4.75 & $98 \%$ \\
\hline $4 \mathrm{~A}$ & AIF $=0$ & 5.2 & 0.13 & 0.11 & 0.00 & 4.7 & 4.97 & 1.2 & 0.07 & 0.00 & & & 0.8 & 734 & 86.6 & 1201 & 2.05 & $97 \%$ \\
\hline & AlF $=0$ & 5.1 & 0.13 & 0.10 & 0.04 & 4.6 & 4.97 & 1.2 & 0.07 & 0.27 & 2 & 086 & 0.8 & .718 & 84.6 & 1174 & 2.45 & $99 \%$ \\
\hline $14 \mathrm{C}$ & $\mathrm{AIF}=$ & 5.0 & 0.13 & 0.10 & 0.06 & 4.5 & 4.95 & 1.2 & 0.06 & 0.49 & 2 & & 0.8 & 0.702 & 82.8 & 1149 & 3.15 & $133 \%$ \\
\hline 4D & $A \mathrm{AF}=1 \mathrm{NO} 3=5$ & 4.9 & 0.13 & 0.10 & 0.13 & 4.4 & 5.01 & 1.1 & 0.06 & 1.01 & 2 & 150 & 0.8 & 0.683 & 80.6 & 1118 & 4.17 & $103 \%$ \\
\hline $4 \mathrm{E}$ & $\mathrm{AIF}=2 \mathrm{NO}=5$ & 4.6 & 0.12 & 0.09 & 0.23 & 4.1 & 5.04 & 1.1 & 0.06 & 1.99 & 2 & 1236 & 0.8 & 0.639 & 75.4 & 1046 & 8.91 & $96 \%$ \\
\hline & $A \mid F=3$ NO3 $=5$ & 4.2 & 0.11 & 0.09 & 0.32 & 3.8 & 5.00 & 1.0 & 0.05 & 2.99 & $2 s$ & 1323 & 0.8 & 0.592 & 69.8 & 968 & 12.17 & $94 \%$ \\
\hline $4 G$ & $\mathrm{AIF}=4 \mathrm{NO}=5$ & 4.0 & 0.1 & 0.08 & 0.41 & 3.6 & 5.03 & 0.9 & 0.05 & 4.00 & 29 & 1412 & 0.8 & 0.558 & 65.8 & 913 & 15.03 & $82 \%$ \\
\hline $5 \mathrm{~A}$ & $\mathrm{AlF}=0 \quad \mathrm{NO} 3=6$ & 6.3 & 0.16 & 0.13 & 0.00 & 5.7 & 6.01 & 1.5 & 0.08 & 0.00 & 29 & 1058 & 0.8 & 0.891 & 105.0 & 1457 & 5.46 & $91 \%$ \\
\hline $5 B$ & $\mathrm{AlF}=0.25 \mathrm{NO} 3=6$ & 6.1 & 0.16 & 0.13 & 0.04 & 5.5 & 5.97 & 1.4 & 0.08 & 0.26 & 25 & 1081 & 0.8 & 0.866 & 102.2 & 1418 & 6.35 & $98 \%$ \\
\hline $5 \mathrm{C}$ & Alf $=0.5 \mathrm{NO}=6$ & 6.0 & 0.15 & 0.12 & 0.08 & 5.4 & 5.93 & 1.4 & 0.08 & 0.52 & 2 & 1103 & 0.8 & 0.844 & 99.5 & 1380 & 7.01 & $99 \%$ \\
\hline 5D & $\mathrm{AIF}=1 \mathrm{NO} 3=6$ & 5.8 & 0.15 & 0.12 & 0.16 & 5.2 & 5.98 & 1.3 & 0.07 & 1.05 & 2 & 1149 & 0.8 & 0.817 & 96.3 & 1336 & 7.66 & $93 \%$ \\
\hline $5 \mathrm{E}$ & $\mathrm{AIF}=2 \mathrm{NO3}=6$ & 5.5 & 0.14 & 0.11 & 0.28 & 4.9 & 6.03 & 1.3 & 0.07 & 1.98 & 2 & 231 & 0.8 & 0.769 & 90.6 & 1258 & 14.78 & $97 \%$ \\
\hline & $\mathrm{AlF}=3 \mathrm{NO}=6$ & 5.1 & 0.13 & 0.10 & 0.39 & 4.5 & 6.01 & 1.2 & 0.07 & 3.02 & 2 & 321 & 0.8 & 0.713 & 84.1 . & 1166 & 20.28 & $92 \%$ \\
\hline $5 G$ & $\mathrm{AlF}=4 \mathrm{NO}=6$ & 4.7 & 0.12 & 0.10 & 0.49 & 4.2 & 5.97 & 1.1 & 0.06 & 4.01 & 2 & 408 & 0.8 & 0.66 & $78.4^{-}$ & 1088 & 18.48 & $88 \%$ \\
\hline $16 \mathrm{~A}$ & $\mathrm{AIF}=$ & 7.4 & 0.27 & 0.15 & 0.00 & 6.7 & 7.05 & 1.7 & 0.14 & 0.00 & 4 & 055 & 0.6 & 0.785 & 92.6 & 1285 & 0.98 & $71 \%$ \\
\hline 16B & $\mathrm{AlF}=0.25 \mathrm{~N}$ & 7.1 & 0.26 & 0.15 & 0.07 & 6.4 & 7.01 & 1.7 & 0.13 & 0.27 & 4 & 088 & 0.6 & 0.764 & 90.1 & 1250 & 9.07 & $116 \%$ \\
\hline $16 \mathrm{C}$ & $\mathrm{AlF}=0.5 \mathrm{NO3}=7$ & 6.9 & 0.25 & 0.14 & 0.13 & 6.2 & 6.96 & 1.6 & 0.13 & 0.51 & 4 & 1118 & 0.6 & 744 & 87.7 & 1217 & 10.07 & $112 \%$ \\
\hline 16D & $\mathrm{AIF}=1 \mathrm{NO}=7$ & 6.8 & 0.25 & 0.14 & 0.1 & 6.1 & 6.98 & 1.6 & 0.12 & 0.73 & 4 & 1145 & 0.6 & 720 & 84.9 & 1178 & 10.52 & $108 \%$ \\
\hline $16 \mathrm{E}$ & $\mathrm{AIF}=2 \quad \mathrm{NO} 3=7$ & 6.6 & 0.24 & 0.13 & 0.24 & 6.0 & 7.03 & 1.5 & 0.12 & 0.99 & 40 & 177 & 0.6 & 678 & 79.9 & 1109 & 12.51 & $115 \%$ \\
\hline $17 \mathrm{~A}$ & $\mathrm{AIF}=0 \quad \mathrm{SO} 4=0$ & 4.7 & 0 & 0.00 & 0.00 & 2.2 & 4.74 & 0.0 & 0.00 & & 0 & 2117 & & 327 & 38.5 & 535 & 21.31 & $106 \%$ \\
\hline $17 \mathrm{~B}$ & AlF $=0 \quad$ SO4 $=0.07$ & 4.7 & 0 & 0.00 & 0.07 & 2.2 & 4.87 & 0.0 & 0.00 & & 0 & 2207 & & 322 & 38.0 & 527 & 10.52 & $99 \%$ \\
\hline $17 \mathrm{C}$ & $\mathrm{AlF}=0 \quad \mathrm{SO} 4=0.14$ & 4.6 & 0 & 0.00 & 0.12 & 2.2 & 4.97 & 0.0 & 0.00 & & 0 & 2278 & & 319 & 37.6 & 522 & 9.72 & $100 \%$ \\
\hline ul17D & $\mathrm{AlF}=0 \quad \mathrm{SO} 4=0.17$ & 4.6 & 0 & 0.00 & 0.14 & 2.2 & 5.03 & 0.0 & 0.00 & & 0 & 2314 & & 317 & 37.4 & 519 & 7.90 & $101 \%$ \\
\hline Pu117E & $\mathrm{AlF}=0 \quad \mathrm{SO} 4=0.21$ & 4.6 & 0 & 0.00 & 0.17 & 2.2 & 5.08 & 0.0 & 0.00 & & 0 & 2350 & & 0.315 & 37.2 & 516 & 5.69 & $99 \%$ \\
\hline Pul18A & $\mathrm{AlF}=0 \quad \mathrm{NO}=4$ & 4.1 & 0.16 & 0.07 & 0.00 & 0.3 & 4.00 & 1.0 & 0.08 & 0.00 & 486 & 11985 & 0.4 & 0.050 & 5.9 & 82 & 0.68 & $9 \%$ \\
\hline Pul18B & $\mathrm{AlF}=0.25 \mathrm{NO}=4$ & 4.0 & 0.16 & 0.06 & 0.04 & 0.3 & 3.98 & 0.9 & 0.08 & 0.27 & 486 & 12382 & 0.4 & 0.048 & 5.7 & 79 & 0.87 & $96 \%$ \\
\hline Pu118C & $\mathrm{AlF}=0.5 \mathrm{NO3}=4$ & 3.9 & 0.15 & 0,06 & 0.08 & 0.3 & 3.95 & 0.9 & 0.08 & 0.50 & 486 & 12735 & 0.4 & 0.047 & 5.5 & 76 & 1.11 & $96 \%$ \\
\hline Pu118D & $\mathrm{AlF}=1 \mathrm{NO} 3=4$ & 3.6 & 0.14 & 0.06 & 0.14 & 0.3 & 3.91 & 0.9 & 0.07 . & 1.00 & 486 & 13482 & 0.4 & 0.044 & 5.1 & 71 & 1.86 & $92 \%$ \\
\hline Pul18E & $\mathrm{AIF}=2 \mathrm{NO}=4$ & 3.2 & 0.12 & 0.05 & 0.25 & 0.3 & 3.84 & 0.8 & 0.06 & 1.99 & 486 & 14965 & 0.4 & 0.038 & 4.5 & 63 & 5.01 & $91 \%$ \\
\hline Pul18F & $\mathrm{AIF}=3 \mathrm{NO} 3=4$ & 2.9 & 0.11 & 0.04 & 0.34 & 0.2 & 3.79 & 0.7 & 0.06 & 3.02 & 486 & 16497 & 0.4 & 0.034 & 4.1 & 56 & 7.99 & $80 \%$ \\
\hline Pu118G & $\mathrm{AIF}=4 \mathrm{NO}=4$ & 2.6 & 0.1 & 0.04 & 0.40 & 0.2 & 3.74 & 0.6 & 0.05 & 4.00 & 486 & 17975 & 0.4 & 0.031 & 3.7 & 51 & 8.77 & $67 \%$ \\
\hline
\end{tabular}


Table A2. Measured Flowrates from Minibank Runs.

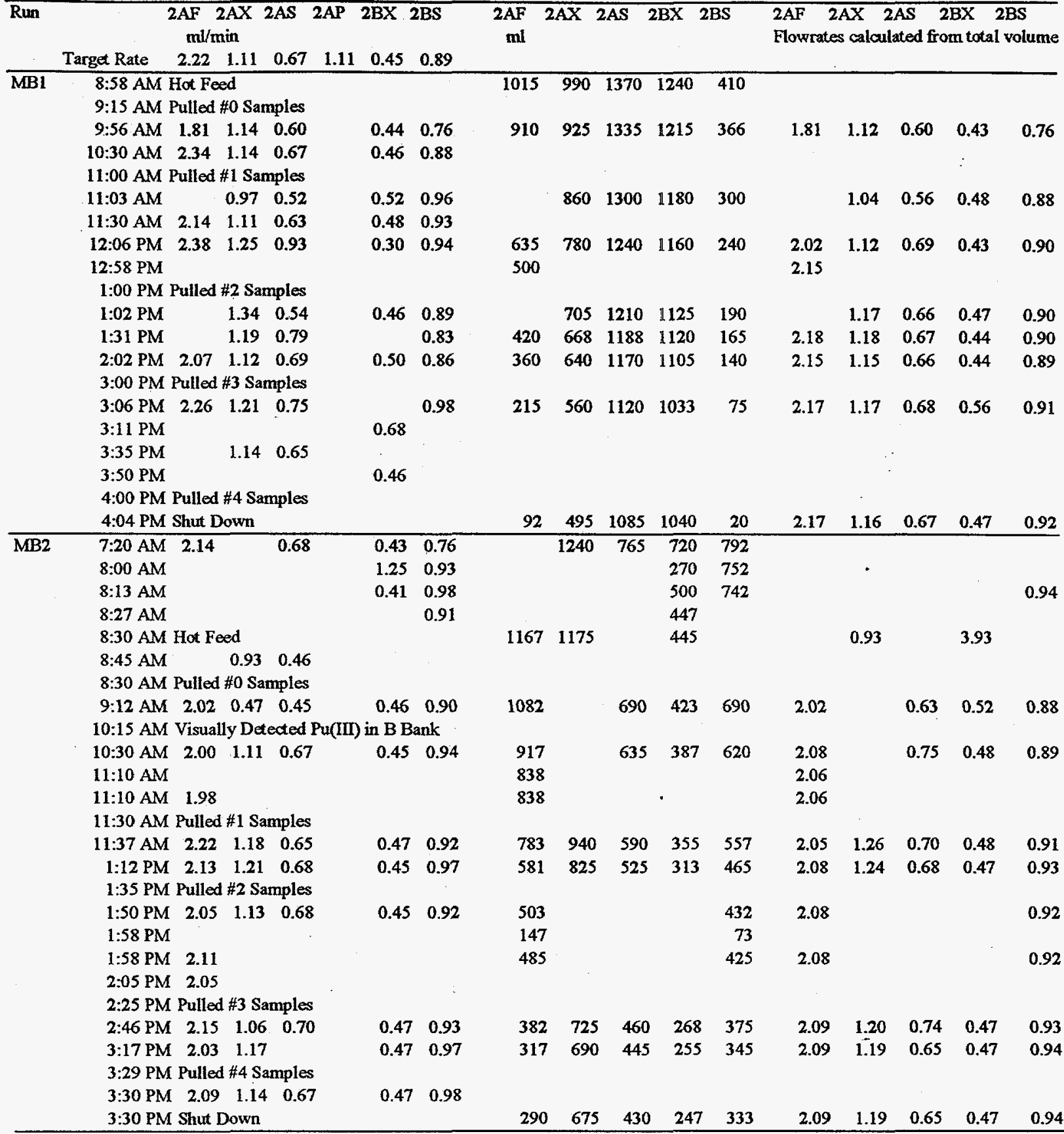


Table A3. Detailed Sample Results from Minibank Run 1.

\begin{tabular}{|c|c|c|c|c|c|c|c|c|c|}
\hline \multicolumn{2}{|c|}{$\begin{array}{l}\text { Sample } \\
\text { ID }\end{array}$} & $\begin{array}{l}\text { ADD } \\
\text { No. }\end{array}$ & $\begin{array}{l}\text { Total } \\
\text { alpha } \\
\text { uCi/ml }\end{array}$ & Am241 & $\mathrm{uCi} / \mathrm{ml}$ & $\mathrm{mg} / \mathrm{l}$ & $\begin{array}{c}\text { Alpha } \\
\text { Am241 } \\
\%\end{array}$ & $\begin{array}{c}\text { Acid } \\
\text { Free } \\
M\end{array}$ & $\begin{array}{c}\mathrm{D} \mathrm{o} / \mathrm{a} \\
\mathrm{Pu}\end{array}$ \\
\hline MBI & A01A & $3-104183$ & 43.47 & 0.00349 & 43.46 & 603.0 & $0.008 \%$ & 0.635 & \\
\hline MB1 & A01O & $3-104173$ & 84.84 & 0.00539 & 84.84 & 1177.1 & $0.006 \%$ & & 1.952 \\
\hline MB1 & A02A & $3-104184$ & 58.93 & 0.00473 & 58.93 & 817.6 & $0.008 \%$ & 0.629 & \\
\hline MB1 & A02O & 3-104174 & 106.99 & 0.00574 & 106.99 & 1484.5 & $0.005 \%$ & 0.101 & 1.816 \\
\hline MB1 & $\mathrm{A} 04 \mathrm{~A}$ & $3-104185$ & 45.97 & 0.0069 & 45.97 & 637.8 & $0.015 \%$ & 0.771 & \\
\hline MB1 & A04O & $3-104175$ & 116.19 & 0.00739 & 116.18 & 1612.0 & $0.006 \%$ & 0.215 & 2.527 \\
\hline MB1 & A06A & $3-104186$ & 22.23 & 0.01182 & 22.22 & 308.3 & $0.053 \%$ & 1.305 & \\
\hline MB1 & $\mathrm{A} 060$ & $3-104176$ & 104.07 & 0.00593 & 104.06 & 1443.9 & $0.006 \%$ & 0.290 & 4.683 \\
\hline MB1 & A08A & 3-104187 & 22.19 & 0.29835 & 21.89 & 303.8 & $1.34 \%$ & 3.154 & \\
\hline MB1 & $\mathrm{A} 08 \mathrm{O}$ & 3-104177 & 91.95 & 0.01416 & 91.93 & 1275.6 & $0.015 \%$ & 0.730 & 4.199 \\
\hline MB1 & AlOA & 3-104188 & 5.39 & 0.30425 & 5.09 & 70.6 & $5.64 \%$ & 3.253 & \\
\hline MB1 & Al0o & $3-104178$ & 24.78 & 0.01221 & 24.77 & 343.7 & $0.049 \%$ & 0.667 & 4.869 \\
\hline MB1 & A12A & 3-104189 & 1.24 & 0.31179 & 0.93 & 12.9 & $25.12 \%$ & & \\
\hline MB1 & $\mathrm{A} 12 \mathrm{O}$ & $3-104179$ & 4.97 & 0.01379 & 4.96 & 68.8 & $0.50 \%$ & & 5.336 \\
\hline MB1 & A14A & $3-104190$ & 0.50 & 0.30277 & 0.20 & 2.8 & $60.37 \%$ & 3.340 & \\
\hline MB1 & A140 & $3-104180$ & 0.89 & 0.00931 & 0.88 & 12.2 & $1.05 \%$ & 0.739 & 4.411 \\
\hline MBI & A16A & 3-104191 & 0.37 & 0.29803 & 0.07 & 1.0 & $81.31 \%$ & 2.965 & \\
\hline MB1 & Al6o & 3-104181 & 0.14 & 0.01711 & 0.12 & 1.7 & $12.26 \%$ & 0.703 & 1.788 \\
\hline MB1 & B02A & 3-104192 & 0.22 & & 0.22 & 3.0 & & & \\
\hline MB1 & $\mathrm{B} 02 \mathrm{O}$ & $3-104182$ & 0.01 & & 0.01 & 0.1 & & & 0.034 \\
\hline MB1 & B04A & 3-104193 & 3.13 & & 3.13 & 43.4 & & & \\
\hline MB1 & B040 & $3-104212$ & 0.08 & & 0.08 & 1.0 & & & 0.024 \\
\hline MB1 & B06A & $3-104194$ & 25.16 & & 25.16 & 349.1 & & 0.402 & \\
\hline MB1 & $\mathrm{B} 060$ & 3-104213 & 1.23 & & 1.23 & 17.1 & & 0.054 & 0.049 \\
\hline MB1 & $\mathrm{B} 08 \mathrm{~A}$ & 3-104195 & 104.07 & & 104.07 & 1443.9 & & & \\
\hline MB1 & B08O & $3-104214$ & 9.86 & & 9.86 & 136.9 & & & 0.095 \\
\hline MB1 & $\mathrm{B} 10 \mathrm{~A}$ & $3-104196$ & 201.03 & & 201.03 & 2789.3 & & 0.582 & \\
\hline $\mathrm{MBI}$ & $\mathrm{B} 100$ & $3-104215$ & 28.34 & & 28.34 & 393.2 & & 0.077 & 0.141 \\
\hline MB1 & B11A & 3-104197 & 232.79 & & 232.79 & 3230.0 & & 0.601 & \\
\hline MB1 & B110 & $3-104216$ & 35.98 & & 35.98 & 499.3 & & 0.063 & 0.155 \\
\hline MB1 & B12A & 3-104198 & 252.86 & & 252.86 & 3508.4 & & 0.575 & \\
\hline MB1 & B12O & $3-104217$ & 47.65 & & 47.65 & 661.1 & & 0.068 & 0.188 \\
\hline MB1 & $\mathrm{B} 13 \mathrm{~A}$ & 3-104199 & 242.83 & & 242.83 & 3369.2 & & 0.565 & \\
\hline $\mathrm{MB1}$ & $\mathrm{B} 130$ & $3-104218$ & 29.51 & & 29.51 & 409.4 & & 0.065 & 0.122 \\
\hline MB1 & B14A & $3-104200$ & 229.87 & & 229.87 & 3189.4 & & 0.535 & \\
\hline MB1 & $\mathrm{B} 140$ & 3-104219 & 8.99 & & 8.99 & 124.7 & & 0.071 & 0.039 \\
\hline MB1 & B16A & $3-104201$ & 225.27 & & 225.27 & 3125.6 & & 0.333 & \\
\hline MBI & $\mathrm{B} 160$ & $3-104220$ & 2.35 & & 2.35 & 32.6 & & 0.050 & 0.010 \\
\hline MB1 & $2 \mathrm{AF}$ & $3-104010$ & 48.06 & 0.39184 & 47.67 & 661.4 & $0.82 \%$ & 3.836 & \\
\hline MB1 & 2AWO & $3-104202$ & 0.01 & 0.00061 & 0.008 & 0.11 & $6.93 \%$ & 2.925 & \\
\hline MB1 & 2AW1 & $3-104203$ & 0.38 & 0.31686 & 0.063 & 0.88 & $83.31 \%$ & 3.136 & \\
\hline MB1 & $2 \mathrm{AW} 2$ & $3-104204$ & 0.38 & 0.32148 & 0.058 & 0.81 & $84.62 \%$ & 3.078 & \\
\hline MB1 & $2 A W 3$ & 3-104205 & 0.38 & 0.30581 & 0.070 & 0.98 & $81.30 \%$ & 3.027 & \\
\hline MBI & 2AW4 & 3-104206 & 0.37 & 0.31666 & 0.055 & 0.77 & $85.13 \%$ & 2.999 & \\
\hline MB1 & 2BP0 & $3-104207$ & 0.05 & & 0.05 & 0.7 & & 0.320 & \\
\hline MB1 & 2BP1 & $3-104208$ & 60.18 & & 60.18 & 835.1 & & 0.375 & \\
\hline MB1 & 2BP2 & 3-104209 & 185.57 & & 185.57 & 2574.7 & & 0.300 & \\
\hline MBI & $2 \mathrm{BP} 3$ & $3-104210$ & 241.99 & & 241.99 & 3357.6 & & 0.323 & \\
\hline MB1 & 2BP4 & $3-104211$ & 251.60 & & 251.60 & 3491.0 & & 0.447 & \\
\hline MB1 & 2BWO & $3-104221$ & 0.000 & & 0.000 & 0.00 & & 0.027 & \\
\hline MB1 & $2 \mathrm{BW} 1$ & $3-104222$ & 0.003 & & 0.003 & 0.04 & & 0.000 & \\
\hline MB1 & $2 \mathrm{BW} 2$ & $3-104223$ & 0.007 & & 0.007 & 0.10 & & 0.000 & \\
\hline MB1 & $2 \mathrm{BW} 3$ & $3-104224$ & 0.006 & & 0.006 & 0.09 & & 0.000 & \\
\hline MB1 & 2BW4 4 & 3-104225 & 0.008 & & 0.008 & 0.11 & & 0.022 & \\
\hline
\end{tabular}


Table A4. Detailed Sample Results from Minibank Run 2.

\begin{tabular}{|c|c|c|c|c|c|c|c|c|c|}
\hline $\begin{array}{c}\text { Sar } \\
\text { ID }\end{array}$ & mple & $\begin{array}{l}\text { ADD } \\
\text { No. }\end{array}$ & $\begin{array}{r}\text { Total } \\
\text { alpha } \\
\text { uCi/ml }\end{array}$ & $\mathrm{uCi} / \mathrm{ml}$ & $\mathrm{uCi} / \mathrm{ml}$ & $\mathrm{mg} / \mathrm{l}$ & $\begin{array}{c}\text { Alpha } \\
\text { Am241 } \\
\%\end{array}$ & $\begin{array}{c}\text { Acid } \\
\text { Free } \\
\mathbf{M} \\
\end{array}$ & $\begin{array}{c}\text { D o/a } \\
\mathrm{Pu}\end{array}$ \\
\hline $\mathrm{MB2}$ & A01A & $3-104397$ & 48.90 & 0 & 48.90 & 678.48 & $0.01 \%$ & 0.618 & \\
\hline MB2 & A010 & 3-104424 & 85.68 & 0 & 85.68 & 1188.79 & $0.00 \%$ & 0.115 & 1.752 \\
\hline MB2 & A02A & 3-104398 & 65.62 & 0 & 65.62 & 910.44 & $0.00 \%$ & 0.652 & \\
\hline MB2 & $\mathrm{A} 02 \mathrm{O}$ & $3-104425$ & 122.04 & 0 & 122.04 & 1693.30 & $0.00 \%$ & 0.117 & 1.860 \\
\hline MB2 & A04A & 3-104399 & 71.47 & 0 & 71.47 & 991.62 & $0.02 \%$ & 0.816 & \\
\hline MB2 & A04O & 3-104426 & 128.73 & 0 & 128.73 & 1786.08 & $0.00 \%$ & 0.159 & 1.801 \\
\hline MB2 & $\mathrm{A} 06 \mathrm{~A}$ & $3-104400$ & 66.45 & 0 & 66.45 & 922.04 & $0.00 \%$ & 1.541 & \\
\hline MB2 & $\mathrm{A} 06 \mathrm{O}$ & $3-104427$ & 115.77 & 0 & 115.77 & 1606.31 & $0.00 \%$ & 0.305 & 1.742 \\
\hline MB2 & $\mathrm{A} 08 \mathrm{~A}$ & $3-104401$ & 34.19 & 0.31412 & 33.87 & 470.00 & $0.92 \%$ & 4.388 & \\
\hline MB2 & $\mathrm{A} 08 \mathrm{O}$ & 3-104428 & 78.99 & 0.00628 & 78.99 & 1095.92 & $0.01 \%$ & 0.831 & 2.332 \\
\hline MB2 & A10A & $3-104402$ & 13.00 & 0.28663 & 12.71 & 176.37 & $2.21 \%$ & 3.900 & \\
\hline MB2 & A100 & $3-104429$ & 40.16 & 0.01453 & 40.15 & 557.08 & $0.04 \%$ & & 3.159 \\
\hline MB2 & $\mathrm{A} 12 \mathrm{~A}$ & $3-104403$ & 1.70 & 0.3621 & 1.33 & 18.52 & $21.34 \%$ & & \\
\hline MB2 & A12O & $3-104430$ & 7.61 & 0.01217 & 7.59 & 105.37 & $0.16 \%$ & & 5.690 \\
\hline MB2 & $\mathrm{A} 14 \mathrm{~A}$ & 3-104404 & 0.56 & 0.34719 & 0.21 & 2.90 & $62.46 \%$ & 4.553 & \\
\hline MB2 & $\mathrm{A} 140$ & $3-104431$ & 1.27 & 0.01083 & 1.26 & 17.54 & $0.85 \%$ & 0.925 & 6.057 \\
\hline MB2 & A16A & 3-104405 & 0.40 & 0.3709 & 0.03 & 0.38 & $93.12 \%$ & 4.484 & \\
\hline MB2 & A. 160 & 3-104432 & 0.23 & 0.01214 & 0.21 & 2.96 & $5.38 \%$ & 0.878 & 7.794 \\
\hline MB2 & $\mathrm{B} 02 \mathrm{~A}$ & 3-104406 & 0.27 & & 0.27 & 3.81 & & & \\
\hline MB2 & $\mathrm{B} 02 \mathrm{O}$ & $3-104433$ & 0.04 & & 0.04 & 0.60 & & & 0.158 \\
\hline MB2 & B04A & 3-104407 & 2.69 & & 2.69 & 37.35 & & & \\
\hline MB2 & B04O & $3-104434$ & 0.13 & & 0.13 & 1.80 & & & 0.048 \\
\hline MB2 & $\mathrm{B} 06 \mathrm{~A}$ & $3-104408$ & 18.68 & & 18.68 & 259.21 & & 0.352 & \\
\hline MB2 & $\mathrm{B} 06 \mathrm{O}$ & $3-104435$ & 0.94 & & 0.94 & 13.05 & & 0.031 & 0.050 \\
\hline MB2 & $\mathrm{B} 08 \mathrm{~A}$ & 3-104409 & 84.42 & & 84.42 & 1171.39 & & 0.430 & \\
\hline MB2 & B080 & 3-104436 & 6.35 & & 6.35 & 88.14 & & 0.053 & 0.075 \\
\hline MB2 & $\mathrm{B} 10 \mathrm{~A}$ & 3-104410 & 201.03 & & 201.03 & 2789.30 & & 0.612 & \\
\hline MB2 & $\mathrm{B} 100$ & 3-104437 & 21.19 & & 21.19 & 294.01 & & 0.364 & 0.105 \\
\hline MB2 & B12A & $3-104411$ & 256.62 & & 256.62 & 3560.57 & & 0.534 & \\
\hline MB2 & $\mathrm{B} 12 \mathrm{O}$ & 3-104438 & 19.23 & & 19.23 & 266.75 & & 0.076 & 0.075 \\
\hline MB2 & B14A & 3-104412 & 232.79 & & 232.79 & 3230.03 & & 0.493 & \\
\hline MB2 & B140 & $3-104439$ & 5.31 & & 5.31 & 73.65 & & 0.071 & 0.023 \\
\hline MB2 & $\mathrm{B} 16 \mathrm{~A}$ & $3-104413$ & 215.66 & & 215.66 & 2992.27 & & 0.382 & \\
\hline MB2 & $\mathrm{B} 160$ & $3-104440$ & 2.55 & & 2.55 & 35.32 & & 0.033 & 0.012 \\
\hline MB2 & $2 \mathrm{AF}$ & $3-104012$ & 55.17 & 0.44302 & 54.73 & 759.32 & $0.80 \%$ & 5.345 & \\
\hline MB2 & 2AW0 & $3-104414$ & 0.01 & 0.00042 & 0.008 & 0.11 & $5.07 \%$ & 3.122 & \\
\hline MB2 & 2AW1 & 3-104415 & 0.40 & 0.33765 & 0.066 & 0.92 & $83.63 \%$ & 4.209 & \\
\hline MB2 & 2AW2 & 3-104416 & 0.38 & 0.33296 & 0.045 & 0.62 & $88.13 \%$ & 3.982 & \\
\hline MB2 & 2AW3 & $3-104417$ & 0.38 & 0.34432 & 0.038 & 0.52 & $90.14 \%$ & 4.267 & \\
\hline MB2 & $2 \mathrm{AW} 4$ & 3-104418 & 0.38 & 0.34949 & 0.035 & 0.49 & $90.89 \%$ & 4.223 & \\
\hline MB2 & 2BP0 & 3-104419 & 0.91 & & 0.91 & 12.58 & & 0.214 & \\
\hline MB2 & 2BP1 & 3-104420 & 48.48 & & 48.48 & 672.68 & & 0.345 & \\
\hline MB2 & 2BP2 & $3-104421$ & 186.40 & & 186.40 & 2586.34 & & 0.326 & \\
\hline MB2 & 2BP3 & 3-104422 & 229.03 & & 229.03 & 3177.84 & & 0.365 & \\
\hline MB2 & 2BP4 & $3-104423$ & 228.20 & & 228.20 & 3166.24 & & 0.371 & \\
\hline MB2 & 2BW0 & 3-104441 & 0.028 & & 0.028 & 0.39 & & 0.007 & \\
\hline MB2 & 2BW1 & $3-104442$ & 0.029 & & 0.029 & 0.40 & & & \\
\hline MB2 & 2BW2 & 3-104443 & 0.041 & & 0.041 & 0.56 & & & \\
\hline MB2 & $2 \mathrm{BW} 3$ & $3-104444$ & 0.038 & & 0.038 & 0.53 & & & \\
\hline MB2 & 2BW4 & 3-104445 & 0.046 & & 0.046 & 0.64 & & 0.009 & \\
\hline
\end{tabular}

